\title{
Review Article \\ Significance and Biological Importance of Pyrimidine in the Microbial World
}

\author{
Vinita Sharma, ${ }^{1}$ Nitin Chitranshi, ${ }^{2,3}$ and Ajay Kumar Agarwal ${ }^{4}$ \\ ${ }^{1}$ School of Pharmacy, Lloyd Institute of Management \& Technology, Plot. No. 11, Knowledge Park II, Greater Noida, \\ Uttar Pradesh 201306, India \\ ${ }^{2}$ Bioinformatics Centre, Biotech Park, Sector G, Jankipuram, Lucknow, Uttar Pradesh 226021, India \\ ${ }^{3}$ Gautam Buddh Technical University, IET Campus, Sitapur Road, Lucknow, Uttar Pradesh 226021, India \\ ${ }^{4}$ Department of Pharmaceutical Sciences, University Institute of Pharmaceutical Sciences, Kurukshetra University, \\ Kurukshetra, Haryana 136119, India
}

Correspondence should be addressed to Nitin Chitranshi; nitin.biotechpark@gmail.com

Received 1 September 2013; Revised 13 January 2014; Accepted 14 January 2014; Published 23 March 2014

Academic Editor: Armando Rossello

Copyright (C) 2014 Vinita Sharma et al. This is an open access article distributed under the Creative Commons Attribution License, which permits unrestricted use, distribution, and reproduction in any medium, provided the original work is properly cited.

\begin{abstract}
Microbes are unique creatures that adapt to varying lifestyles and environment resistance in extreme or adverse conditions. The genetic architecture of microbe may bear a significant signature not only in the sequences position, but also in the lifestyle to which it is adapted. It becomes a challenge for the society to find new chemical entities which can treat microbial infections. The present review aims to focus on account of important chemical moiety, that is, pyrimidine and its various derivatives as antimicrobial agents. In the current studies we represent more than 200 pyrimidines as antimicrobial agents with different mono-, di-, tri-, and tetrasubstituted classes along with in vitro antimicrobial activities of pyrimidines derivatives which can facilitate the development of more potent and effective antimicrobial agents.
\end{abstract}

\section{Introduction}

Resistance to antimicrobial agents has become an increasingly important and pressing global problem. Of the 2 million people who acquire bacterial infection in US hospitals each year, $70 \%$ of cases now involve strains that are resistant to at least one drug [1]. In communities and hospitals around the world, the number of patients with antibioticresistant infections continues to climb [2]. A major cause for concern in the UK is methicillin-resistant Staphylococcus aureus (MRSA), which was at low levels a decade ago but now accounts for ca. $50 \%$ of all S. aureus isolates [3]. Substantial investment and research in the field of anti-infectives are now desperately needed if a public health crisis is to be averted. The causes of antimicrobial resistance are multifactorial. In case of an antibiotic, it has been well documented that resistance is mainly caused by continued overreliance on and imprudent use of these antibacterial agents [4] and increasing evidence is being obtained suggesting that the same may be true for the emergence of biocide resistance
$[5,6]$. Of particular concern is the possible cross-resistance of antibiotics and biocide due to common resistance mechanism $[7,8]$. Metal resistance is being observed as the result of polluted environments $[9,10]$. The consequence of continued exposure to antibacterial environment is an enrichment of bacteria that are intrinsically resistant to antimicrobials or have acquired resistance mechanism to these substances [11, 12].

Structural modification of antimicrobial drugs to which resistance has developed has been proven to be an effective means of extending the lifespan of antifungal agents such as the azoles [13], antiviral agents such as the nonnucleoside reverse transcriptase inhibitors [14], and various antibacterial agents including $\beta$-lactams and quinolones [15]. It is not surprising then that, in response to antimicrobial resistance, major pharmaceutical companies have tended to concentrate their efforts on improving antimicrobial agents in established classes [16]. However, with the portfolio of chemotherapeutics currently available, it has been acknowledged that researchers are getting close to the end game in terms of 


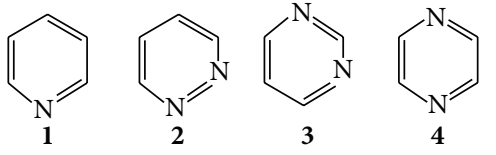

Figure 1: Pyridine and different isomeric forms of diazine family.

parent structure alterations. A call has therefore been made for the development of new classes of drugs that work on different target sites to those in current use [17, 18].

Heterocyclic compounds are abundant in nature and are of great significance to life because their structural subunits exist in many natural products such as vitamins, hormones, and antibiotics [19, 20]; hence, they have attracted considerable attention in the design of biologically active molecules $[21,22]$ and advanced organic chemistry [23, 24]. Also in the family of heterocyclic compounds nitrogen containing heterocycles are an important class of compounds in the medicinal chemistry and also contributed to the society from biological and industrial point which helps to understand life processes [25]. A totally unsaturated membered six-ring containing nitrogen is known as azine [26] or pyridine (1); with two nitrogen atoms it is known as diazine [27], and with a nitrogen at 1,2-position, it is known as pyridine (2), at 1,3position as pyrimidine (3), and at 1,4-position as pyrazine (4) (Figure 1). However, the current review intends to focus on the significance of pyrimidine class of antimicrobial agents along with clinical and in vitro applications of pyrimidine derivatives to facilitate the development of more potent as well as effective antimicrobial agents.

\section{Pyrimidine: General Introduction}

Pyrimidines (5) are the heterocyclic aromatic compounds similar to benzene and pyridine containing two nitrogen atoms at positions 1 and 3 of the six membered rings. Heterocycles containing pyrimidine moiety are of great interest because they constitute an important class of natural and nonnatural products, many of which exhibit useful biological activities and clinical applications [28, 29]. Substituted purines and pyrimidines occur very widely in living organisms and were some of the first compounds studied by the organic chemists [30] (Figure 2(a)).

Pyrimidines are biologically very important heterocycles and represent by far the most ubiquitous members of the diazine family with uracil (6) and thymine (7) being constituents of ribonucleic acid (RNA) and deoxyribonucleic acid (DNA) and with cytosine (8) both being present in Figure 2(b).

In addition to this, pyrimidines skeleton is also present in many natural products such as vitamin $B_{1}$ (thiamine) and many synthetic compounds, such as barbituric acid (9) and Veranal (10) which are used as hypnotics [31] (Figure 2(b)).

\section{Medicinal Properties of Pyrimidines}

The presence of pyrimidine base in thymine, cytosine, and uracil, which are the essential building blocks of nucleic acids DNA and RNA, is one possible reason for their widespread therapeutic applications. The pyrimidines represent one of the most active classes of compounds possessing wide spectrum of biological activities like significant in vitro activity against unrelated DNA and RNA, viruses including polioherpes viruses, diuretic, antitumour, antiHIV, and cardiovascular [32]. The literature survey indicated that a wide range of pharmacological activities are exhibited by the compounds encompassing pyrimidines nucleus. In addition to this, various analogs of pyrimidines have been found to posses antibacterial [33-39], antifungal [40-43], antileishmanial [44], anti-inflammatory [45, 46], analgesic [47], antihypertensive [48, 49], antipyretic [50], antiviral [5153], antidiabetic [54], antiallerggic [55], anticonvulsant [56], antioxidant [57, 58], antihistaminic [59], herbicidal [60], and anticancer activities [61-64] and many of pyrimidines derivatives are reported to possess potential central nervous system (CNS) depressant properties $[65,66]$ and also act as calcium channel blockers [67].

\section{Clinical and Pharmacological Applications of Pyrimidine in the Microbial World: Marketed Drugs}

During the last two decades several pyrimidine derivatives have been developed which are found to have wideclinical and pharmacological applications [68].

4.1. Antibacterial Agents. Drugs which are included in this category are antifolates possessing antagonistic activity against folic acid and sulfa drugs which are sulphur containing pyrimidine derivative drugs.

4.1.1. Antifolates. 2-Amino-4-hydroxypyrimidines are found to be antagonists of folic acid [69]; hence, a large number of 2,4-diaminopyrimidines have been synthesized as antifolates and it was eventually proved that these pyrimidines are inhibitors dihydrofolate reductase (DHFR) [70, 71]. Notable amongst the 2,4-diaminopyrimidine drugs are the following.

Trisubstituted Pyrimidine Containing Drugs. Brodiprim (11) is found to be an effective antibacterial compound [72]. Iclaprim (12) which is a new selective dihydrofolate inhibitor was synthesized based on rational drug design and this drug is found to be active against methicillin-, TMP-, and vancomycin-resistant strains [73, 74]. Trimethoprim (13) is an antibacterial drug which selectively inhibits bacterial DHFR [75] (Figure 3).

Tetrasubstituted Pyrimidine Containing Drug. Pyrimethamine (14) is a selective inhibitor of the DHFR of malarial plasmodia [75] (Figure 3).

4.1.2. Sulfa Drugs. Pyrimidine containing sulfa drugs are classified on the basis of substitution and the classification with the respective example of drug is as follows. 


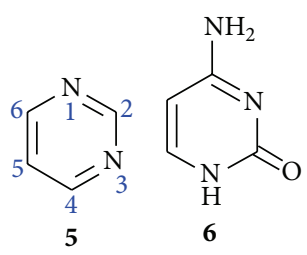

(a)<smiles>O=c1cc[nH]c(=O)[nH]1</smiles>

7<smiles>Cc1c[nH]c(=O)[nH]c1=O</smiles><smiles>O=C1CC(=O)NC(=O)N1</smiles><smiles>CCC1(CC)C(=O)NC(=O)NC1=O</smiles>

Figure 2: (a) Pyrimidine. (b) Pyrimidine containing natural and synthetic products.<smiles>COc1cc(Cc2cnc(N)nc2N)cc(OC)c1Br</smiles>

11<smiles>COc1cc(Cc2cnc(N)nc2N)c2cc[c+](C3CC3)oc2c1OC</smiles>

12<smiles>COc1ccc(Cc2cnc(N)nc2N)c(OC)c1OC</smiles>

13<smiles>Cc1nc(N)nc(N)c1-c1ccc(Cl)cc1</smiles>

14

FIGURE 3: Antibacterial drugs (antifolates) containing trisubstituted and tetrasubstituted pyrimidines.

Monosubstituted and disubstituted sulfa drugs include sulfadiazine (15), sulfamerazine (16), sulfadimidine (sulfamethazine) (17), sulfameythoxydiazine (18), and methyldiazine (19) (Figure 4). Sulfadiazine, sulfamerazine, and sulfadimidine are superior to other sulfonamides and are used in some acute bacterial infections, cerebrospinal meningitis, and patients allergic to penicillins [68]. Sulfameythoxydiazine (18) possesses a good half life and methyldiazine (19) possesses a longest half life of about $65 \mathrm{~h} \mathrm{[76].}$

Trisubstituted sulfa drugs include sulfadoxine (20), sulfisomidine (21), sulfadimethoxine (22), sulfamethoxine (23), sulfamethomidine (24), and sulfacytine (25) (Figure 4).

Sulfadoxine which has a half life of 7-9 days is used for malarial prophylaxis [77] whereas sulfisomidine with a half life of $7 \mathrm{hr}$ is used as a combination sulfa therapy in human serum hemolytic complement system [78]. Sulfadimethoxine was introduced in 1959 with a half life of approximately $40 \mathrm{hr}$ and the related 4 -sulfamidopyrimidine and sulfamethoxine, having two methoxy groups in 5 and 6 positions, have by far the longest half life of about of $65 \mathrm{hr}$. Further, a new broad-spectrum sulfonamide, sulfamethomidine, is relatively nontoxic and patients do need extra fluid to intake and sulfacytinehas been reported to be 3-10 times more potent than sulfaisoxazole and sulfisomidine [76].

Sulfa drugs are known to possess good antibacterial activity in combination with trimethoprim [2,4-diamino-5(3,4,5-trimethoxy benzyl pyrimidine)], resulting in synergistic effect [79]. Sulfonamide-trimethoprim combinations are used extensively for opportunistic infections in patients with Acquired Immunodeficiency Syndrome (AIDS) [80].

4.2. Antibiotics. Antibiotics containing pyrimidines moiety are further classified on the basis of substitution on the ring.
Disubstituted Pyrimidine Containing Antibiotic Drug. Amicetin (26) is cytosine derivative which exhibits activity against acid fast and Gram-positive bacteria as well as some other organisms [81] (Figure 5).

Trisubstituted Pyrimidine Containing Antibiotic Drug. Plicacetin (26) is another cytosine derivative which exhibits activity against bacteria [81]. The simplest pyrimidine antibiotic of all is bacimethrin (28) (5-hydroxy-2-methoxypyrimidin-4-amine) which is active against several staphylococcal infections [81]. Gourgetin (29) is a cytosine derivative which is active against mycobacteria as well as several Grampositive and Gram-negative bacteria (Figure 5). Aminoglycoside antibiotics phleomycin, bleomycin and related families are wide-spectrum antibiotics containing the ring pyrimidine ring [82]. Bleomycin (see Figure S1 in Supplementary Material available online at http://dx.doi.org/10.1155/2014/202784) is already in clinical use against certain tumours like Hodgkin's lymphoma and disseminated testicular cancer [83].

4.3. Antivirals and Anti-HIV (AIDS) Agents. Pyrimidines derivatives also possess good antiviral properties; for example, 5-iododeoxyuridine (30) and IDU (5-iodo- $2^{\prime}$ deoxyuridine) (31) have been extensively utilized for viral infections. 5-Trifluoromethyl-2'-deoxyuridine (32) has been found useful against infections resistant to IDU therapy [84]. 1-(3-Azido-2,3-dideoxypentofuranosyl)-5-methyl-2,4(1H,3H)pyrimidinedione (33) is a potent inhibitor of the in vivo replication and cytopathic effects of HIV and has been approved for use against AIDS and severe AIDS-Related Complex (ARC) [85] (Figure 6).

Lamivudine (34) is an effective anti-AIDS when used in combination with zidovudine; cidofovir (35) is used for 
<smiles>Cc1ccc(S(=O)(=O)Nc2ncccn2)cc1</smiles>

15<smiles>Cc1ccc(NS(=O)(=O)c2ccc(C)nc2)nc1</smiles>

19<smiles>Cc1ccc(S(=O)(=O)Nc2nccc(C)n2)cc1</smiles>

16<smiles>COc1ncnc(NS(=O)(=O)c2ccc(N)cc2)c1OC</smiles>

20<smiles>Cc1ccc(S(=O)(=O)Nc2nc(C)cc(C)n2)cc1</smiles>

17<smiles>COc1cnc(NS(=O)(=O)c2ccc(C)cc2)nc1</smiles>

18<smiles>COc1ncnc(S(=O)(=O)Nc2ccc(N)cc2)c1OC</smiles>

23<smiles>COc1cc(NS(=O)(=O)c2cccc(N)c2)nc(C)n1</smiles>

24<smiles>COc1cc(NS(=O)(=O)c2ccc(N)cc2)nc(OC)n1</smiles>

21

FIGURE 4: Sulfa drugs having monosubstituted (15), disubstituted (16-19), and trisubstituted (20-25) pyrimidine.<smiles>O=C(NC1=NCN(C2OC(CO)C(O)C2O)C=C1)c1ccccc1</smiles>

26<smiles></smiles>

27<smiles>COCc1cc(N)nc(C)n1</smiles>

28<smiles>CC1OC(N2CC=C(N)NC2=O)C=CC1NC(=O)CC(N)CCN(C)/C=N/N</smiles>

29

FIGURE 5: Antibiotics representing disubstituted (26) pyrimidine moiety and trisubstituted (27-29) pyrimidine moiety.

the treatment of cytomegalovirus (CMV) [86]. Zidovudine (36) which is an analogue of thymidine in which the azido group is substituted at the 3-position of the dideoxyribose moiety is active against RNA tumour viruses (retroviruses) that are the causative agents of AIDS and T-cell leukaemia. Zalcitabine (37) is another useful drug and is given in combination with Zidovudine [87]. Stavudine (38), a pyrimidine nucleoside, is found to show significant activity against $\mathrm{HIV}$ virus when given in combination with zidovudine [88].
4.4. Antifungal Drugs. Pyrimidines also exhibit antifungal properties (see Figure 7). Flucytosine (39) is a fluorinated pyrimidine and is an orally active antifungal agent which is used for the treatment of serious systemic infections caused by susceptible strains of Candida and Cryptococcus $[89,90]$ and hexetidine (40) is mainly used for the treatment of aphthous ulceration [91]. Recently, voriconazole (41) is a disubstituted drug undergoing phase III comparative clinical trials to establish its full potential as a broad-spectrum antifungal agent $[92,93]$. 
<smiles>O=c1[nH]c(=O)n(C2CC(O)C(CO)O2)cc1I</smiles>

30<smiles>COC[C@H]1O[C@@H](n2cc(I)c(=O)[nH]c2=O)C[C@@H]1O</smiles>

31<smiles>COC[C@H]1O[C@@H](n2cc(C(F)(F)F)c(=O)[nH]c2=O)C[C@@H]1O</smiles>

32<smiles>Cc1cn(C2CC(N)C(CO)O2)c(=O)[nH]c1=O</smiles>

33<smiles>Nc1ccn(C2CSC(CO)O2)c(=O)n1</smiles>

34<smiles>Nc1ccn(C[C@H](CO)CCP(=O)(O)O)c(=O)n1</smiles>

35<smiles></smiles>

36<smiles>Cc1cn(C2CCC(CO)O2)c(=O)nc1N</smiles>

37<smiles>Cc1cn(C2C=CC(CO)O2)c(=O)[nH]c1=O</smiles>

38

FIGURE 6: Antiviral drugs having pyrimidine moiety.<smiles>Nc1nc(=O)[nH]cc1F</smiles>

39<smiles>CCCCC(CC)CN1CN(CC(CC)CCCC)CC(C)(N)C1</smiles>

40<smiles>CC(c1ncncc1F)C(O)(Cn1cncn1)c1ccc(F)cc1F</smiles>

41

FIgURE 7: Pyrimidine containing antifungal drugs.

\section{In Vitro Antimicrobial Activity Profile of Pyrimidines: Literature Review}

In the past few years great advances have been made in the synthesis of novel pyrimidines derivatives with a potent antimicrobial activity. The following review will examine the in vitro antimicrobial activity of pyrimidines, a class of heterocyclic compounds possessing a diverse range of pharmacological properties. The in vitro antimicrobial activity is further divided into antibacterial, antifungal, antimycobacterial, antituberculosis, antileishmanial, antiamoebic, antiparasitic, and antiviral activities on the basis of its activity against the particular microorganisms and these activities are briefly discussed in turn, with particular emphasis on pyrimidine moiety along with their SAR studies (structure activity relationships).

5.1. Antibacterial Activity and Antifungal Activity. This is the first category to be described here which consists of pyrimidine derivatives possessing activity against the various strains of bacteria and fungi. These various pyrimidine derivatives were further divided on the basis of substitution on the pyrimidine ring and this classification is as follows.
5.1.1. Monosubstituted and Disubstituted Pyrimidine Derivatives. Kolotova et al. synthesized dicarboxylic acid 2-pyrimidylamides derivatives and evaluated the in vitro antibacterial activity of the synthesized compounds with respect to the standard strains of E. coli and $S$. aureus. The compounds (42-45) exhibited an in vitro antibacterial activity against all the tested strains with MIC value equal to $500-1000 \mu \mathrm{g} / \mathrm{mL}$ [94]. Hydrazone derivatives of vanillin are found to possess potent antibacterial activity. Based on higher bioactivity of hydrazones, new hydrazone derivatives (46) were synthesized from piperidine-4carboxylic acid methyl ester and checked for antibacterial activities by paper diffusion method by measuring the zone of inhibition in millimeters against Pseudomonas aeruginosa and Staphylococcus aureus bacterial strains and compared with standard drugs ciprofloxacin and cefaclor. The zone of inhibition of tested compounds shows the vanillin coupled hydrazone derivatives encompass potent bioactivities against bacterial strains [95] (Figure 8).

Pyrimidine salt such as 4-methyl-3-(4-pyridin-3-ylpyrimidin-2-ylamino)-phenyl ammonium-2,5-dichloro-4hydroxy-3,6-dioxo-cyclohexa-1,4-dienolate (47) chloranilic acid was synthesized and screened for in vitro antibacterial activity. Results revealed that the above compound exhibited 
<smiles>O=C(O)/C=C\C(=O)Nc1ncccn1</smiles>

42<smiles>C/C(=C/C(=O)Nc1ncccn1)C(=O)O</smiles>

43<smiles>O=C(O)CCC(=O)Nc1ncccn1</smiles>

44<smiles>O=C(/C=C(\C(=O)O)c1ccccc1[N+](=O)[O-])Nc1ncccn1</smiles>

45<smiles>[R20]c1ccc(/C=N/NC(C)C2CCC(c3ncccn3)CC2)cc1OC</smiles>

$46 \mathrm{R}=\mathrm{H}, \mathrm{CH}_{3}, \mathrm{C}_{4} \mathrm{H}_{9}, \mathrm{CH}_{2} \mathrm{CH}_{2} \mathrm{OCH}_{3}$<smiles>COc1c(N)ccc(C)c1Nc1nccc(-c2cccnc2)n1</smiles>

47

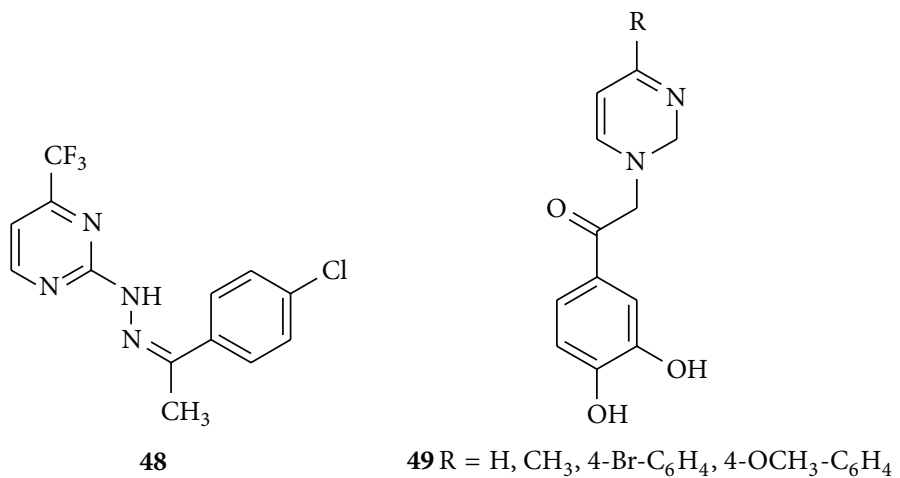

FIgURE 8: Monosubstituted pyrimidine derivatives with antibacterial and antifungal activity.

good activity with the zone of inhibition in the range of $16 \mathrm{~mm}$ against pathogenic bacterial strains and good antifungal activity with the $56.4 \%$ inhibition against $F$. oxysporum when compared with the standard drug [96] (Figure 8).

In search of new T. cruzi inhibitor, Zanatta et al. in 2008 synthesized a series of novel 2-( $N^{\prime}$-benzylidinehydrazino $)-4$ trifluoromethyl pyrimidines derivatives and evaluated them to inhibit the growth of T. cruzi. The compound (48) was found to be the most active compound and was able to produce most significant inhibitory effect $(80 \%)$ and presented an $\mathrm{IC}_{50}$ value of $85 \mu \mathrm{M}$ [97]. Balan et al. synthesized some new diazinium salts with dihydroxyacetophenone and screened them for their antibacterial activity against $S$. aureus, $S$. saprophyticus, Sarcina lutea, B. subtilis, B. cereus, E. coli, and $P$. aeruginosa and antifungal activity against $C$. albicans and found that the compound (49) showed excellent antibacterial and antifungal activity which is much more than that of chloramphenicol and almost similar to that of nystatin [98] (Figure 8).

5.1.2. Trisubstituted Pyrimidine Derivatives. A novel series of mercaptopyrimidine and aminopyrimidine derivatives of indoline-2-one were synthesized by Mondal et al. and screened for their in vitro antibacterial activity against Grampositive bacteria Staphylococcus aureus, Bacillus subtilis and Gram-negative bacteria Salmonella typhi, Shigella dysenteriae, Pseudomonas mirabilis, and Escherichia coli. It was found that compounds (50) and (51) with a methoxy $\left(\mathrm{OCH}_{3}\right)$ substitution on phenyl ring at para position and hydroxyl $(-\mathrm{OH})$ group at ortho position were found potent and (-Cl) substitution showed a very good zone of inhibition at concentration of $100 \mu \mathrm{g} / \mathrm{mL}$ against both Gram-positive and Gram-negative bacteria, comparable to standard drug Ampicillin [99]. Further derivatives of aminopyrimidines were synthesized by Solankee et al. and evaluated for their in vitro antibacterial activity against various bacterial strains. Compound (50) was found to show small amount of activity against $S$. aureus [100]. Sukhwal and Verma synthesized the novel series of 2piperidin-4,6-diaryl substituted pyrimidines by carrying out the reaction between the S-benzylisothiouronium chloride (SBT) with variously substituted chalcones and evaluated the synthesized compounds for their in vitro antibacterial activity. Results revealed that the compounds (53) and (54) showed the maximum to moderate activity against Klebsiella pneumonia, Pseudomonas vulgaris, E. coli, and Pseudomonas aeruginosa [101]. A novel series of 2-amino-4-(4'chlorophenyl)-6-(substituted)-pyrimidines were synthesized by Desai et al. and they evaluated the compounds for in vitro 
<smiles>COc1ccc(/N=C2\C(=O)N(c3cc(-c4ccc(Cl)cc4)nc(S)n3)c3ccccc32)cc1</smiles>

50<smiles>c1ccc(-c2cc(-c3ccccc3)nc(N3CCCCC3)n2)cc1</smiles>

53<smiles>[R]c1ccc(-c2cc(-c3ccc([R])cc3)nc(NS(=O)(=O)c3ccc(NC(C)=O)cc3)n2)cc1</smiles>

56<smiles>Nc1nc(-c2ccc(Cl)cc2)cc(N2C(=O)/C(=N\c3ccccc3Cl)c3ccccc32)n1</smiles>

51<smiles>COc1ccc(-c2cc(-c3ccccc3)nc(N3CCCCC3)n2)cc1</smiles>

54

\begin{tabular}{|c|c|c|}
\hline $\mathbf{5 6}$ & $\mathrm{R}^{1}$ & $\mathrm{R}^{2}$ \\
\hline $\mathbf{a}$ & $\mathrm{NO}_{2}$ & $\mathrm{CH}_{3}$ \\
\hline $\mathbf{b}$ & $\mathrm{NO}_{2}$ & $\mathrm{OCH}_{3}$ \\
\hline $\mathbf{c}$ & $\mathrm{CH}_{3}$ & $\mathrm{OCH}_{3}$ \\
\hline $\mathbf{d}$ & $\mathrm{OCH}_{3}$ & $\mathrm{OCH}_{3}$ \\
\hline e & $\mathrm{Cl}$ & $\mathrm{OCH}_{3}$ \\
\hline $\mathbf{f}$ & $\mathrm{NO}_{2}$ & $\mathrm{NO}_{2}$ \\
\hline
\end{tabular}<smiles>Nc1nc(-c2ccc(Cl)cc2)cc(-c2cc(F)c(Cl)cc2F)n1</smiles>

FIGURE 9: Trisubstituted pyrimidine derivatives of antibacterial and antifungal activity.

antibacterial activity. Results revealed that the compound (55) showed the highest antibacterial activity against E. coli, Salmonella (Gram -ve) and Bacillus pumilus, micrococcus (Gram +ve) [102] (Figure 9).

Wasfy and Aly reported some new derivatives of diphenylysulfapyrimidine acetates synthesized by the condensation of sulfaguanidine acetate with chalcones bearing an electron withdrawing group. Results revealed that all the compounds were weakly or moderately active and the compound (56) having combination of substituents like $\mathrm{Cl}, \mathrm{OCH}_{3}$, and $\mathrm{NO}_{2}$ possessed fairly marked activity whereas compound (56f) bearing 2-nitro group (electron withdrawing group) had activity comparable to commercial antibacterial agent sulfadiazine [103]. With the view of physiological importance and pharmaceutical properties of 2amino pyrimidines, Devi et al. synthesized some derivatives 2-amino-4-(2', $4^{\prime}$-dichloro, $5^{\prime}$ fluro)-6-phenyl pyrimidine and evaluated them for in vitro antibacterial activity. Results showed that the compound (55) having chloro group showed moderate activity on all strains of bacteria [104] (Figure 9).

Some more derivatives of pyrimidines having benzofuryl ring were reported by Yadav et al. who evaluated the in vitro antimicrobial activity of the compounds. It was found that the compounds (58-62) showed good activity against
B. subtilis, E. coli, A. niger, and C.albicans [105]. Kothari et al. synthesized some new 2-(1-piperidinyl/1-pyrrolidinyl)4-substituted phenyl-6 ( $3^{\prime}, 5^{\prime}$-dibromo- $4^{\prime}$-hydroxy phenyl)pyrimidine derivatives and evaluated the synthesized compounds against Gram-positive organisms Streptococcus viridians and $S$. aureus and Gram-negative organisms E. coli and K. pneumonia. The compound (63) was found to display moderate activity [106] (Figure 10).

Some substituted pyrimidines derivatives containing benzofuran have been synthesized by Babu et al. and screened for the in vitro antimicrobial activity. Results revealed that the compounds (64-66) if suitably substituted were found to show antibacterial and antifungal activity, that is, against P. aeruginosa, S. aureus, and C. albicans [107]. Pasha et al. prepared 4,6-disubstituted pyrimidine-thiones and 2-amino4,6-disubstituted pyrimidines by interaction of various chalcones and evaluated them for in vitro antibacterial and antitubercular activities and it was found that compounds (67) and (68) showed moderate activity against B. subtilis, $S$. aureus, E. coli, and Pseudomonas aeruginosa [108] (Figure 10).

Chandrasekharan and Nagarajan synthesized some novel 2-amino-6-aryl-4-(2-thienyl) pyrimidines and evaluated the compounds for in vitro antibacterial activity. Results revealed that the halogen substituted 4-fluoro, that is, compound (69), 
<smiles>CCCCCCCCCc1cc(C2Cc3ccccc3O2)nc(N)n1</smiles>

58

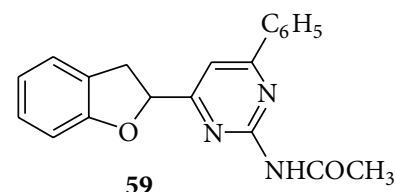

59<smiles>COc1ccc(-c2cc(C3Cc4ccccc4O3)nc(/N=C/c3ccc(Cl)cc3)n2)cc1</smiles>

60<smiles>COc1ccc(-c2cc(C3Cc4ccccc4O3)nc(NC(=O)CCl)n2)cc1</smiles><smiles>[R]CNc1nc(-c2ccc([Al])cc2)cc(C2Cc3ccccc3O2)n1</smiles><smiles>[R]c1nc(-c2ccc([R])c([R])c2)cc(-c2cc(Br)c(O)c(Br)c2)n1</smiles><smiles>[R]c1cc(C2Cc3ccccc3O2)nc(N)n1</smiles>

64<smiles>[R]c1cc(C2Cc3ccccc3O2)nc(S)n1</smiles>

65<smiles>[R]c1cc(C2Cc3ccccc3O2)nc(O)n1</smiles>

66<smiles>[R]c1ccc(-c2cc(-c3ccc([R])cc3)[nH]c(=S)n2)cc1</smiles>

67<smiles>[R]c1ccc(C2=CC(c3cc[Y1]([H])cc3)=NC(N)N2)cc1</smiles>

68

\begin{tabular}{|c|c|c|c|c|c|}
\hline $\mathbf{6 7 - 6 8}$ & $\mathrm{R}^{1}$ & $\mathrm{R}^{2}$ & $\mathbf{6 7 - 6 8}$ & $\mathrm{R}^{1}$ & $\mathrm{R}^{2}$ \\
\hline $\mathbf{a}$ & $\mathrm{H}$ & $2-\mathrm{Cl}$ & $\mathbf{f}$ & $4-\mathrm{NH}_{2}$ & $4-\mathrm{CH}_{3}$ \\
\hline $\mathbf{b}$ & $\mathrm{H}$ & $2-\mathrm{NO}_{2}$ & $\mathbf{g}$ & $4-\mathrm{NH}_{2}$ & $2-\mathrm{NO}_{2}$ \\
\hline $\mathbf{c}$ & $\mathrm{H}$ & $3-\mathrm{NO}_{2}$ & $\mathbf{h}$ & $4-\mathrm{NH}_{2}$ & $2-\mathrm{NO}_{2}$ \\
\hline $\mathbf{d}$ & $\mathrm{H}$ & $4-\mathrm{NO}_{2}$ & $\mathbf{i}$ & $2,4-\mathrm{Cl}$ & $3,4,5-\mathrm{OCH}_{3}$ \\
\hline $\mathbf{e}$ & $\mathrm{H}$ & $3,4,5-\mathrm{OCH}_{3}$ & & & \\
\hline
\end{tabular}

FIGURE 10: Trisubstituted pyrimidine derivatives of antibacterial and antifungal activity.

was found to be more active than 4-chloro, 4-bromo and the rest of other compounds [109]. Novel pyrimidines quinoline clubbed molecules were synthesized by Patel and Mehta who studied their in vitro antibacterial activity of all the synthesized compounds against the S. aureus, Streptococcus pyogenes, E. coli, and $P$. aeruginosa and antifungal activity against $C$. albicans, $A$. niger. Results showed that the presence of methoxy and halogen groups $(\mathrm{Cl}, \mathrm{Br}$, and $\mathrm{F})$ in the phenyl ring of the compound (70) increases the antimicrobial activity [110]. In 2006, Kumar et al. synthesized aminopyrimidines bearing benzofuran ring and evaluated them for their in vitro antibacterial activity against $P$. aeruginos $a$ and $S$. aureus and antifungal activity against $A$. niger and Curvularia. All compounds (71) showed comparable antimicrobial activities with chloramphenicol and fluconazole which were used as standards for comparison of antimicrobial and antifungal activity, respectively [111]. Recently reported morphilino pyrimidines were synthesized by Kanagarajan et al. under microwave irradiation and screened for their in vitro antibacterial activity against B. subtilis, Bacillus cereus, Micrococcus luteus, and Salmonella typhi and antifungal activity against A. niger, Candida 6, and Candida 51. Structure activity relationship results for the synthesized compounds showed that compound (72) which has electron withdrawing chloro, fluoro, bromo, and nitro functional groups at the para/meta position of phenyl rings attached to C- 4 and C- 6 carbons of pyrimidine moiety delivered excellent antibacterial and antifungal activities [112] (Figure 11).

In 2007, Naik and Chikhalia synthesized a series of 2-[\{2(Morpholino)-3-pyridinyl-5-thio\}-2-oxoethyl oxadiazolyl]amino-4-(2,4-dichloro-5-fluoro phenyl)-6-(aryl)-pyrimidines and screened them for their antibacterial activity against 
<smiles>Nc1nc(-c2ccc(Br)cc2)cc(-c2cccs2)n1</smiles>

69<smiles>[X]c1ccc(-c2cc(-c3ccc(OC)cc3)nc(Nc3cc4cc(C)ccc4nc3C)n2)cc1</smiles>

$70 \mathrm{X}=\mathrm{F}, \mathrm{Br}$<smiles>NC1=NC(c2ccc(Cl)cc2)CC(c2cc3ccccc3o2)=N1</smiles>

71<smiles>[R]c1ccc(-c2cc(-c3ccc(N4CCOCC4)cc3)nc(N)n2)cc1[R]</smiles><smiles>[R]c1ccc(-c2cc(-c3cc(F)c(Cl)cc3Cl)nc(NC(=O)CSc3nnc(-c4cccnc4N4CCOCC4)o3)n2)cc1</smiles><smiles>[R]c1cccc(-c2cc(-c3cccc4ccccc34)nc(N)n2)c1</smiles>

$72 \mathrm{R}^{1}=\mathrm{H}, \mathrm{CH}_{3}, \mathrm{Cl}, \mathrm{F}, \mathrm{Br}, \mathrm{OCH}_{3}$ $\mathrm{R}^{2}=\mathrm{H}, \mathrm{Cl}, \mathrm{F}, \mathrm{NO}_{2}$<smiles>Oc1nc(-c2ccc(I)cc2)cc(C2Cc3cc(Br)ccc3O2)n1</smiles>

75 $73 \mathrm{R}=4-\mathrm{CH}_{3}-\mathrm{C}_{6} \mathrm{H}_{4}, 3,4,5-\left(\mathrm{OCH}_{3}\right)_{3}-\mathrm{C}_{6} \mathrm{H}_{2}$ $74 \mathrm{R}=\mathrm{F}, \mathrm{Cl}$<smiles>[R]c1ccc(-c2cc(C3Cc4cc(Br)ccc4O3)nc(S)n2)cc1</smiles><smiles>[R]C(=O)Nc1ccc(O)c(-c2cc([R])nc(N)n2)c1</smiles>

78<smiles>[R]c1cc(-c2cc(NC(C)=O)ccc2O)nc(-n2cc([R])nc2S)n1</smiles>

\begin{tabular}{|c|c|c|}
\hline 78-79 & $\mathrm{R}^{1}$ & $\mathrm{R}^{2}$ \\
\hline $\mathbf{a}$ & $4-\mathrm{CH}_{3}-\mathrm{C}_{6} \mathrm{H}_{4}$ & - \\
\hline $\mathbf{b}$ & $4-\mathrm{NO}_{2}-\mathrm{C}_{6} \mathrm{H}_{4}$ & - \\
\hline $\mathbf{c}$ & $2-T h i e n y l$ & - \\
\hline $\mathbf{d}$ & $\mathrm{C}_{6} \mathrm{H}_{5}$ & $\mathrm{CH}_{3}$ \\
\hline $\mathbf{e}$ & $4-\mathrm{Cl}^{-\mathrm{C}_{6}} \mathrm{H}_{4}$ & $\mathrm{C}_{6} \mathrm{H}_{5}$ \\
\hline $\mathbf{f}$ & $4-\mathrm{NO}_{2}-\mathrm{C}_{6} \mathrm{H}_{4}$ & $\mathrm{C}_{6} \mathrm{H}_{5}$ \\
\hline $\mathbf{g}$ & $4-\mathrm{Br}^{-} \mathrm{C}_{6} \mathrm{H}_{4}$ & $\mathrm{C}_{6} \mathrm{H}_{5}$ \\
\hline $\mathbf{h}$ & $2-$-Furyl & $\mathrm{C}_{6} \mathrm{H}_{5}$ \\
\hline $\mathbf{i}$ & $2-$ Thienyl & $\mathrm{C}_{6} \mathrm{H}_{5}$ \\
\hline
\end{tabular}

FIGURE 11: Trisubstituted pyrimidine derivatives of antibacterial and antifungal activity.

S. aureus, E. coli, S. typhi, and B. subtilis. It was found that in comparison to standard drug compound (73) showed maximum zone of inhibition against E.coli, S. aureus, S. typhi, and $B$. subtilis [113]. A series of novel 2-amino-4-(1-napthyl)6 -aryl pyrimidines has been synthesized by Ingarsal et al. and evaluated for in vitro antibacterial and antifungal activities against representative bacteria-S. aureus, E. coli, K. pneumonia, and $P$. aeruginosa and fungi-Trichophyton tonsurans and Microsporum gypseum. It was found that compound (74) having 4-fluoro and 4-chloro groups had the best overall antibacterial and antifungal activities [114]. 4-(5-Bromo-1benzofuran-2-yl)-6-(substituted phenyl)-pyrimidine-2-ol (75) and 4-(5-bromo-1-benzofuran-2-yl)-6-(substituted phenyl)-pyrimidine-2-thiol (76) were synthesized by Kumar et al. and subjected to in vitro antibacterial and antifungal activity. The compound possessed significant antibacterial activity against $B$. subtilis, $P$. aeruginosa and antifungal against A. niger and C. albican [115]. Recently, Ramesh and Sumana synthesized novel pyrimidines derivatives by combining chalcones of 2-acetyl thiophene with guanidine hydrochloride in the presence of alcohol and subjected the synthesised compounds to in vitro antibacterial and antifungal activity. It was found that, among the synthesized compounds, the compound (77) showed maximum antibacterial and antifungal activity at both $0.05 \mathrm{~mL}$ and $0.1 \mathrm{~mL}$ of concentration due to the presence of chloro and nitro groups as pharmacophores [116]. Patil et al. reported the synthesis of some new pyrimidines derivatives bearing paracetamol and imidazolyl moieties. The synthesized compounds (78) and (79) have been found to be active against Rhizobium species, E. coli, Fusarium oxysporum, and Curvularia lunata [117] (Figure 11).

More recently, a novel series of 4-[4-(2,4-dichloro-5-fluorophenyl)-6-(4-methoxyphenyl)pyrimidine-2-yl]-1-(arylaminocarbnyl/thiocarbonyl)semicarbazides $\quad(\mathbf{8 0})$ were synthesized by Patel et al. and evaluated for their in vitro antibacterial activity against Gram-positive bacteria 
(S. aureus and B. subtilis) and Gram-negative bacteria (E. coli and P. aeruginosa). Results revealed that all the synthesized compounds exhibited excellent or moderate activity, also the substitution of electron withdrawing group on aromatic ring always optimizez the lead compound [118]. Data of antimicrobial activity of compound (81) synthesized by Forsch et al. revealed that the compound showed potent in vitro antibacterial activity in comparison to trimethoprim and was found to be 12,000 times more potent than trimethoprim and its potency actually exceeded that of trimethoprim by a factor of at least 10 [119]. A subsequent paper has checked out the in vitro antibacterial activity of 4-substituted 2-amino-6-(aniline) pyrimidines and screened them as selective inhibitors of DNA polymerase III in $S$. aureus. The compound (82) was found to be 5-fold more active than the prototype of 4-chloro compound having $97 \%$ inhibition because the presence of small hydrophobic substituents on the 3 and 4 positions of the aniline group combined with 4-halosubstituted phenoxy substituents was always found to increase the anti-Pol III activities of these Gram-positive selective inhibitors [120]. N,NDimethyl-4-phenyl-5-[phenyl (1H-1,2,4-triazol-1-yl) methyl] pyrimidine-2-amine was synthesized by Menozzi et al. and screened for antibacterial activity. The compound (83) showed activity against S. aureus with MIC value 66 $\mu \mathrm{M}$ and this was the only compound showing antifungal activity against $C$. albicans and $C$. neoformans due to the presence of pyrimidine nucleus bearing a double aromatic substitution at positions 2 and 4 [121]. Nassar synthesized the oxo- and thioxopyrimidines derivatives and screened them for their in vitro bactericidal activity against $S$. aureus, E. coli, and $P$. aeruginosa. The screened compound (84) showed high or moderate bactericidal activity compared to that of ciprofloxacin [122]. Novel 4-[3-(2-Amino-4-(4-chlorophenyl)pyrimidine-6-yl)-4-hydroxybenzyl]-2-(amino-4(4-methoxyphenyl)pyrimidine-6-yl) phenol derivatives have been reported by Nagaraj and Reddy in 2008 and the compound (85) was found to be highly active against pathogenic bacteria E. coli, S. aureus, and B. subtilis and fungi C. albicans due to the presence of methoxy group at position 4 [123] (Figure 12).

A novel series of 2-thiouracil-5-sulfonamide derivatives were synthesized and investigated for in vitro antibacterial, antifungal, antiviral, and antitumour activities. Outcome of Structure Activity Relationship (SAR) study depicted the thiouracil nucleus as essential for the antimicrobial activity and substitution at position 5 of 2-thiouracil gave active compounds as antibacterial, antiviral, and antineoplastic; hence, the substituents group like thiourea in compound (86), pyridine moiety in compound (87), benzene nucleus with $\mathrm{NO}_{2}$ group in compound (88), and thiazole ring in compound (89) were found to show potent in vitro antimicrobial activity [124]. Chikhalia et al. in 2008 synthesized some newly substituted quinolinyl chalcones containing pyrimidines moiety and evaluated the in vitro antibacterial activity. The compound (90) and its various derivatives with an electron withdrawing group on the aromatic ring like 4-chloro or 2-methoxy and presence of more than one electron withdrawing group like 3,4,5-methoxy were found to show excellent activity against $S$. aureus and B. subtillis when compared with standard Ampicillin trihydrate [125] (Figure 12).

In another study, novel 2,4-diaminopyrimidines bearing $\mathrm{N}, \mathrm{N}$-disubstituted aminomethyl residues at the position 5 were designed as dihydrofolate reductase (DHFR) inhibitors. Results revealed that a number of compounds belonging mostly to the bi-(91), tri-(92) and tetra-(93) cyclic amine series showed a potent inhibitory activity mainly against TMP-sensitive and TMP-resistant DHFR from S. pneumoniae [126]. Some new derivatives of natural dipeptide antibiotics TAN 1057 A, B containing heterocyclic ring and $\beta$-amino acid as a side chain were synthesized and screened for the in vitro antimicrobial activity by Brands et al. Results revealed that the amino pyridyl derivative, that is, compound (94), and amino quinolyl derivative, that is, (95), showed considerable antistreptococcal activity [127] (Figure 13).

With the view of potent antibacterial activity a new series of 4-(1-napthyl)-6-arylpyrimidine-2-(1H)-ones, (96), was synthesized by Vijayaramalingam et al. and evaluated for in vitro antibacterial activity. It was demonstrated from the data of in vitro antibacterial activity that there is an increase in activity profile when groups such as chloro, nitro, and fluoro are present in the phenyl ring [128]. Novel adamantylated pyrimidines were synthesized by Orzeszko et al. and compound (97) was found to possess significant in vitro antibacterial and antifungal activities against all the selected strains [129] (Figure 13).

In the year of 2008, Moustafa et al. synthesized some new derivatives pyrimidines and selected members of the synthesized compounds were screened for in vitro antimicrobial activity. The compound (98) showed higher antibacterial activity than the standard drug (penicillin) while compound (99) showed higher activity against C. albicans than the standard drug (Nystatin) [130]. In another paper Ramiz et al. reported the synthesis of 2, 6 disubstituted pyrimidine derivatives and evaluated their in vitro antibacterial activity. It was demonstrated from the SAR studies that the oxo analogue of pyrimidine, that is, compound (100), showed less activity than the corresponding substituted thiopyrimidine derivatives; that is, compound (101) and 2-hydrazinyl dihydropyrimidine derivative (102) exhibited the highest activity against B. subtilis, P. aeruginosa, and Streptomyces species, with MIC values of $75 \mu \mathrm{g} / \mathrm{mL}$ [131] (Figure 14).

Utilising 2-ethoxymethylene-3-oxobutanenitrile Černuchová et al. synthesized the pyrimidines derivatives. All the synthesized compounds displayed biological activity against bacteria, filamentous fungi, and tumour HeLa cells and the widest antimicrobial activity has been manifested by the compound (103) containing biologically active subunit: a nitro group in position 3 on the phenyl ring against $B$. subtilis, S. aureus, and A. niger [132]. Further, a series of truncated carbocyclic pyrimidine nucleosides were synthesized and evaluated for the in vitro antibacterial activity. The compound (104) (1'S, $\left.2^{\prime} \mathrm{R}, 3^{\prime} \mathrm{S}\right)-1-\left[\left(2^{\prime}, 3^{\prime}\right.\right.$-dihydroxy)$4^{\prime}$-cyclopenten-1'-yl] cytosine was found to be the most active against the selected bacterial strains by inhibiting the S-adenosyl-homocysteine (SAH) hydrolase enzyme [133]. 
<smiles>[X]C(NNC(=O)N[Al])NNC(=O)Nc1nc(-c2ccc(OC)cc2)cc(-c2cc(F)c(Cl)cc2Cl)n1</smiles>

$80 \mathrm{X}=\mathrm{O}, \mathrm{S}$

81<smiles>CCc1cc(Nc2cc(C3C=CC(Br)=CO3)nc(N)n2)ccc1C</smiles>

82<smiles>CCCCCCc1nc(C)ncc1C(CCCCC)n1ccnc1</smiles>

83<smiles>[X]c1nc(-c2ccc(OC)cc2)cc(-c2c[nH]c3ccccc23)n1</smiles><smiles>CNC(=S)N/N=C(\C)c1cccc(NS(=O)(=O)c2c[nH]c(=O)[nH]c2=O)c1</smiles>

86<smiles>COc1ccc(C2=CC(c3cccc(NS(=O)(=O)c4c[nH]c(=O)[nH]c4=O)c3)=NC(=O)C2C#N)cc1</smiles>

87<smiles>O=c1[nH]cc(S(=O)(=O)Nc2ccccc2[N+](=O)[O-])c(=O)[nH]1</smiles>

88<smiles>[R]Oc1cccc(-c2cc(-c3cc(F)c(Cl)cc3Cl)nc(NC(=O)CNc3ccc(C(=O)/C=C/c4cc5ccc(C)cc5nc4N4CCOCC4)cc3)n2)c1</smiles>

FIGURE 12: Trisubstituted pyrimidine derivatives of antibacterial and antifungal activity.

Another prominent work was reported by Micky et al. who synthesized the 1-arylethylene benzofuranyl ketone derivatives having pyrimidine moiety and tested their in vitro antibacterial activity. The compounds (105) and (106) due to the presence of pyrimidine-2-thione moiety were found to show moderate activity against two strains of bacteria B. cerens (Gram positive) and E. coli (Gram negative) by agar diffusion technique [134]. Patel and Gorgamwala reported the synthesis of 2-(pyrazine-2-carboxamido)-4(2-o-aminobenzene sulfonamide-4,6-dimehylpyrimidine)6-arylthiouredio)-s-triazine derivatives and screened them for in vitro antibacterial activity against $S$. aureus and $E$. coli. Amongst the synthesized derivatives compound (107) with the presence of phenyl ring and $-\mathrm{CH}_{3}$ at positions 3 and 4 on the phenyl ring, respectively, showed good activity and the presence of $-\mathrm{OCH}_{3}$ at position 2 displayed good activity 
<smiles>COc1cc2c(c3c1OCO3)C(C)N(Cc1cnc(N)nc1N)CC2</smiles><smiles>CC(C(=O)CC(N)CCCCN)C1CNC(Nc2ccncc2)=NC1=O</smiles><smiles>CC(C(=O)CC(N)CCCCN)C1CNC(Nc2ccnc3ccccc23)=NC1=O</smiles><smiles>[R]c1cc(-c2ccc3ccccc3c2)nc(C)n1</smiles>

$96 \mathrm{R}=\mathrm{C}_{6} \mathrm{H}_{5}, 4-\mathrm{NO}_{2}-\mathrm{C}_{6} \mathrm{H}_{4}, 3-\mathrm{NO}_{2}-\mathrm{C}_{6} \mathrm{H}_{4}, 4-\mathrm{Cl}-\mathrm{C}_{6} \mathrm{H}_{4}, 3-\mathrm{Cl}-\mathrm{C}_{6} \mathrm{H}_{4}$<smiles>CCCCSc1cc(C)cc(C2C3CC4CC(C3)CC2C4)c1</smiles>

FIGURE 13: Trisubstituted pyrimidine derivatives of antibacterial and antifungal activity.<smiles>CC(=O)c1cnc(CCc2cccs2)nc1S</smiles><smiles>CC(=O)c1cnc(CCc2cccs2)nc1SCc1nnc(S)o1</smiles><smiles>O=c1nc(-c2cccs2)cc(-c2ccc(Cl)cc2)[nH]1</smiles><smiles>S=c1nc(-c2cccs2)cc(-c2ccc(Cl)cc2)[nH]1</smiles>

101<smiles>Nc1nc(-c2ccc(Cl)cc2)cc(-c2cccs2)n1</smiles>

102<smiles>Cc1nc(-c2cccc([N+](=O)[O-])c2)ncc1C#N</smiles><smiles>COc1cc2occc2c(OC)c1-c1cc(-c2ccccc2)nc(S)n1</smiles>

105<smiles>COc1cc2occc2c(OC)c1-c1cc(-c2ccccc2)nc(S)n1</smiles>

106<smiles>[R]NC(=S)Nc1nc(NC(N)=O)nc(Nc2cccc(S(=O)(=O)Nc3nc(C)cc(C)n3)c2)n1</smiles>

$107 \mathrm{R}=\mathrm{C}_{6} \mathrm{H}_{5}, 3-\mathrm{OCH}_{3}-\mathrm{C}_{6} \mathrm{H}_{4}, 2-\mathrm{OCH}_{3}-\mathrm{C}_{6} \mathrm{H}_{4}, 2-\mathrm{NO}_{2}-\mathrm{C}_{6} \mathrm{H}_{4}$ FIGURE 14: Trisubstituted pyrimidine derivatives of antibacterial and antifungal activity. 

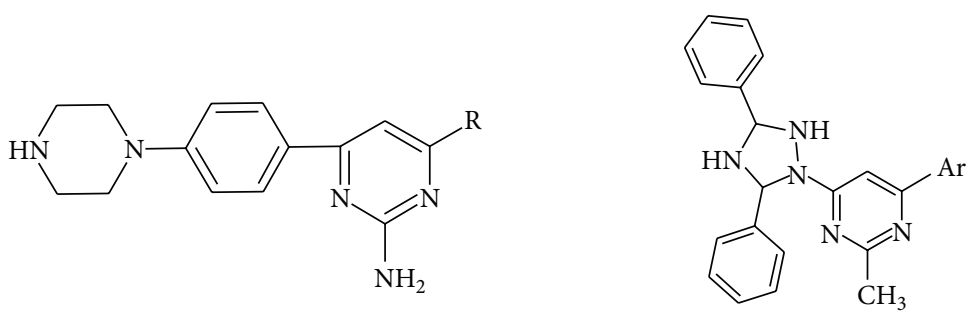

$108 \mathrm{Ar}=2-\mathrm{F}_{-} \mathrm{C}_{6} \mathrm{H}_{4}, 2-\mathrm{Cl}-\mathrm{C}_{6} \mathrm{H}_{4}, 3 \mathrm{Cl}-\mathrm{C}_{6} \mathrm{H}_{4}, 4-\mathrm{Br}^{-} \mathrm{C}_{6} \mathrm{H}_{4}$

$109 \mathrm{Ar}=2-\mathrm{Cl}-\mathrm{C}_{6} \mathrm{H}_{4}, 3-\mathrm{NO}_{2}-\mathrm{C}_{6} \mathrm{H}_{4}, 4-\mathrm{OCH}_{3}-\mathrm{C}_{6} \mathrm{H}_{4}, 4-\mathrm{OH}-\mathrm{C}_{6} \mathrm{H}_{4}$

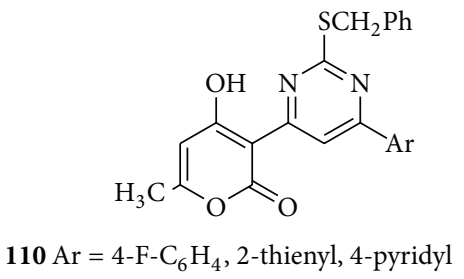<smiles>c1ccc(-c2cccc(-c3cccs3)c2)cc1</smiles>

$111 \mathrm{Ar}=4-\mathrm{NO}_{2}-\mathrm{C}_{6} \mathrm{H}_{4}, 4-\mathrm{Cl}-\mathrm{C}_{6} \mathrm{H}_{4}, 4-\mathrm{OC}_{3}-\mathrm{C}_{6} \mathrm{H}_{4}$, 3- $\mathrm{NO}_{2}-\mathrm{C}_{6} \mathrm{H}_{4}, 4-\mathrm{F}-\mathrm{C}_{6} \mathrm{H}_{4}, 2$-thienyl

FIGURE 15: Trisubstituted pyrimidine derivatives of antibacterial and antifungal activity.

while its presence at the fourth position and $\mathrm{NO}_{2}$ group on the second position of phenyl ring displayed slight to moderate activity [135] (Figure 14).

For the treatment of commonly occurring microbial disease Rahman et al. synthesized some new 2-amino4,6-diarylpyrimidine derivatives (108) by the condensation of chalcone derivatives with guanidine hydrochloride and screened them for in vitro antimicrobial activity against Bacillus subtilis, Bacillus pumilus, Proteus vulgaris, and E.coli. Among the synthesized pyrimidine derivatives particularly halogen substituted derivatives showed more activity when compared with the standard drug ciprofloxacin [136]. Later, Khanage et al. described an efficient method for the synthesis 6-(substituted aryl)-4-(3,5-diphenyl)-1H-1,2,4-triazol1-yl)-1,6-dihydropyrimidine-2-thiol (109) and screened the synthesized compounds for their in vitro antimicrobial activity by agar well method at $50 \mu \mathrm{g} / \mathrm{mL}$ and $100 \mu \mathrm{g} / \mathrm{mL}$ concentrations. Exclusively studied SARs revealed that the presence of methoxy, chloro, nitro, and hydroxyl substitution on phenyl ring of the pyrimidine nucleus produced remarkable in vitro antimicrobial activity against $S$. aureus, E. coli, C. albicans, and A. niger [137] (Figure 15).

Pyrimidine derivatives bearing a pyronyl side in the position 4 have been synthesized by using commercially available dehydroacetic acid (DHA) aromatic aldehydes and S-benzylthiouronium chloride (SBT) and tested for in vitro antimicrobial activity. Among the synthesized derivatives, compound (110) showed mild activity against Gram +ve Bacillus subtilis bacteria and minor activity against Gram -ve $P$. aeruginosa [138]. A novel series of 2-mercaptopyrimidines (111) were synthesized by combining (E)-thienyl chalcones with thiourea in alcohol medium and evaluated for their in vitro antibacterial and antifungal activities against Grampositive organisms (E. faecalis and S. aureus), Gram-negative organisms (K. Pneumoniae and E. coli), and fungi (C. albicans and $A$. niger), also compared with that of the standard drugs ciprofloxacin and fluconazole. The antitubercular activity was carried out by using Middle brook 7H9 agar Blue Assay (MABA) method. The antibacterial results revealed that compounds showed significant activity against Grampositive organisms and moderate activity against the Gramnegativeorganisms when compared with the standard drug and showed significant antitubercular activity with MIC ranging from 0.8 to $6.25 \mu \mathrm{g}$ [139] (Figure 15).

5.1.3. Tetrasubstituted Pyrimidine Derivatives of Antibacterial and Antifungal Activities. A variety of pyrimidines derivatives were synthesized by Aly and Nassar by utilizing $N$ (dicyclomethylazo) phenyl]-2-saccharin-2-ylacetamide and evaluated the derivatives for in vitro antibacterial activity and results revealed that compounds (112-117) showed promising activity towards bacteria [140]. Some novel series of pyrimidines derivatives were also reported by Waheed et al. and screened for their in vitro antibacterial activity. It is found that all the compounds were effective against Gram-negative test and compound (118) having bromo substituent on the meta position of aminopyrimidines showed appreciable activity against E. coli [141]. Parmar and Parikh reported the synthesis of some novel derivatives of pyrimidinethiones and the products have been screened for their in vitro growth inhibitory activities against several microbes like Bacillus megaterium, B. subtilis, E. coli, Pseudomonas Fluorescens, and Aspergillus awamori. It was found that the compounds (119) and (120) exhibited the significant activity [142]. Khir Eldin et al. utilized the 6-amino-2 thiouracil for the synthesis of several heterocyclic derivatives and examined the in vitro antibacterial activity of some products. It is found that the phosphorous containing derivative (121) showed the highest activity and the compounds (122) and (123) showed the moderate activity [143]. Purohi et al. reported the synthesis of the 5- $\left[5^{\prime}\right.$ (mercapto) $]-1,3,4$-oxadiazol-2' -yl,6methyl-4-aryl-3,4-dihydro pyrimidine $2(1 H)$ ones and 5[5' -(aryl)]-1,3,4-oxadiazol-2' -yl,6-methyl-4-aryl-3,4 dihydro 
pyrimidine $2(1 H)$-ones and evaluated them for the the in vitro antimicrobial activities of the compounds. It was found that in comparison to the standard drug the compounds (124) and (125) exhibited the highest activity against $S$. aureus and E.coli and moderate activity against fungal organisms [144] (Figure 16).

Some new derivatives of $\mathrm{S}$ - $\beta$-D-glucosides 4mercaptopyrimidine were synthesized by Moustafa et al. and evaluated for in vitro antimicrobial activity. Results revealed that the compound (126) showed the higher activity against B. subtilis (Gram-positive) and E. coli (Gram-negative) while the compound (127) showed good activity towards fungi whereas compound (128) showed moderate activity [145] (Figure 16).

Upadhyay and Ram synthesized some pyrimidines and azolopyrimidines and evaluated the biodynamic properties of the synthesized compounds and found that the compound (129) was the most potent amongst all and inhibited the in vitro growth of the microbes up to $88 \%$ [146]. New derivatives containing 5-acetyl-4(3,4-dimethoxyphenyl)-6methyl 2-oxo-1,2,3,4-tetrahydropyrimidine moiety incorporated with different biologically active heterocycles such as pyridon, iminopyridines, thiazolidinones, and chalcones and 2-alkoxypyridines derivatives were synthesized and screened for their in vitro antibacterial and antifungal activity by ElFattah et al. The compound (130) in $100 \mu \mathrm{g} / \mathrm{mL}$ gave the highest antibacterial activity against all the tested strains with a mean zone of inhibition equal to $8.5 \mathrm{~mm}$ [147]. Moustafa et al. synthesized and evaluated the 2-amino-5-cyano-6hydroxy-4-phenyl pyrimidines against Gram-positive and Gram-negative bacteria. The synthesized compound (131) was found to be selectively active against Gram-positive $S$. aureus bacteria; also substitution on the aromatic aldehydes reduces the activity [148]. Tomašić et al. synthesized 5-(3,4,5-trifluorobenzylidene) pyrimidine-2,4,6 $(1 \mathrm{H}, 3 \mathrm{H}, 5 \mathrm{H})$ trione and tested it for in vitro antibacterial activity. The compound (132) had a great influence on antibacterial activity since 2,3,4-trifluorobenzylidenebarbituric acid possessed activity against $S$. aureus and mehticillin-resistant S. aureus with minimum inhibitory concentration (MIC) values of $32 \mu \mathrm{g} / \mathrm{mL}$ and $128 \mu \mathrm{g} / / \mathrm{mL}$, respectively [149]. The significant antimicrobial activity was found in 4[(acetylphenyl) amino]-6-(2-methoxyphenyl)]-2-thioxo-1,2dihydropyrimidine-5-carbonitrile derivatives when tested for their in vitro antimicrobial activity by Fathalla et al. Results revealed that the compound (133) possessed the highest antibacterial activity against $E$. coli, Salmonella typhimurium, Listeria monoctyogenes, S. aureus, $P$. aeruginosus, and Bacillus cereus [150] (Figure 17).

The novel series of indole dihydropyrimidine derivatives (134) were synthesized by Heda et al. and screened for their in vitro antibacterial activity against $E$. coli and $P$. aeruginosa and in vitro antifungal activity against $A$. niger and Fusiform oxyporum. The MIC was determined which showed promising results when compared with the standard drug [151]. The novel series of substituted 6-n-propyl thiouracils was synthesized by Prachayasittikul et al. and screened for in vitro antibacterial, antimalarial activities and as cytotoxic agents. The results showed that the compounds (135) and (136) exhibited complete growth inhibition against S. pyogenes, $B$. catarrhalis, and $M$. lutens with a minimum inhibitory concentration ranges of 32-128 $\mu \mathrm{g} / \mathrm{mL}$ [152]. Akbari et al. synthesized new N-(4-chlorophenyl)-6-methyl-4-aryl-2-thioxo1,2,3,4-tetrahydropyrimidine-5-carboxamide (137) and evaluated its in vitro antibacterial and antifungal activities against S. aureus, S. epidermidis, E. coli, P. aeruginosa, and C. albicans, respectively. All the synthesized compounds exhibited moderate activity as compared to the standard [153]. In another work, Moustafa et al. synthesized some Sand $\mathrm{N}-\beta$ - $D$-glucosides derivatives of pyrimidine-4-thiol and evaluated the in vitro antibacterial activity. The compound (138) showed higher activity against B. subtilis as Gram +ve and E. coli as Gram -ve bacteria [154] (Figure 17).

Three novel series of tetrazolo [1,5-a] quinoline derivatives containing pyrimidine moiety were synthesized by Bekhit et al. and screened for their in vitro antibacterial activity. The activity of compounds (139) was 50\% of that of ampicillin against $E$. coli and the compound (140) showed activity against $S$. aureus comparable or half-fold of that of ampicillin [155]. As a result of pioneering work of Qin Yan, a novel series of 5-benzylidene thiobarbiturates (141) derivatives have been synthesized and screened for their antibacterial activity. These compounds exhibited selectively antibacterial activity against S. aureus with the MIC value of $3.1 \mu \mathrm{g} / \mathrm{m}$ [156]. A new class of 1,3-thiazolidine pyrimidine nucleoside analogues were synthesized and evaluated by Sriharsha et al. for the in vitro antibacterial activity. The compound (142) due to the presence of free $\mathrm{NH}$ group in the pyrimidine moiety along with chloro or bromo substitution was always found to show increased and significant activity when compared with bacitracin and ciprofloxacin [157]. A new class of thiopyrimidine derivatives was synthesized by Padmaja et al. and evaluated for its in vitro antibacterial activity against Gram +ve and Gram -ve bacteria. The compounds (143) and (144) exhibited moderate to high activity towards Gram +ve bacteria with an inhibitory zone of $17-22 \mathrm{~mm}$ and moderate activity towards Gram -ve bacteria with an inhibitory zone of 18-25 mm [158]. Ethyl 2-(4-(dimethylamino)-4-methyl-6-phenylpyrimidine5-carboxylate was synthesized regioselectively and evaluated for its in vitro antibacterial activity by Gholap et al. The compound (145) with no substituents on the phenyl ring showed more potent activities having MIC $16 \mu \mathrm{g} / \mathrm{mL}$ which is comparable to that of the standard erythromycin [159] (Figure 18).

A series of dihydropyrimidines (DHPM) derivatives were synthesized and screened for the in vitro antibacterial activity. The compounds (146-147) were found to have significant zone of inhibition against E.coli, E. aerogenes, Bacillus spizizenii, $P$. aeruginosa, E. coli, and some other strains [160]. A new series of 5-[2-(2-methylpropyl-enyl)-1H benzimidazolyl-4,6-diphenyl-pyrimidin-2- $(5 \mathrm{H})$-thione (148) derivatives have been synthesized and subjected to evaluation of their in vitro antibacterial activity against B. subtilis, $S$. aureus, E. coli, and Pseudomonas diminuta by Sharma et al. It was deduced from the data that the compounds containing electron withdrawing groups, that is, nitro, chloro, and methoxy substitution, were found to show enhanced and remarkable antibacterial activity [161]. Septioğlu et al. 
<smiles>Nc1nc(=S)[nH]c(N)c1N=[W]</smiles>

113

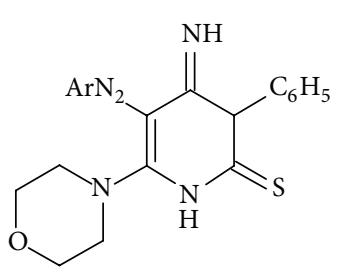

116<smiles>CC1=NC(O)NC(N2CCOCC2)=C1[N+]#N</smiles>

114<smiles>CCCCCCNc1nc(N2CCCCC2)c([N+](=O)[O-])c(=S)[nH]1</smiles>

115<smiles>N#Cc1c(N2CCOCC2)[nH]c(=S)[nH]c1=S</smiles>

117<smiles>CC1=Nc2c(c(C(=O)N3C(=N)N=C(C4C=C5C=CC=CC5OC4=O)CC3c3cccc(C)c3)cc[n+]2C)C(=O)C1</smiles><smiles>[Y]NC(=O)C1=C(C)NC(S)NC1c1cccc([R])c1</smiles><smiles>[Y]NC(=O)C1=C(C)NC(SC)NC1c1cccc([R])c1</smiles><smiles>CC(C)(C)[I+](C)(C)/N=c1/cc([O])[nH]c(=S)[nH]1</smiles>

121<smiles>N#CCSC(=S)Nc1[nH]c(=S)[nH]c(=O)c1CC#N</smiles>

122

$\mathrm{R}^{1}=3-\mathrm{Cl}-\mathrm{C}_{6} \mathrm{H}_{4}, 3,4-\left(\mathrm{OCH}_{3}\right)_{2}-\mathrm{C}_{6} \mathrm{H}_{3}$

$\mathrm{R}^{2}=\mathrm{C}_{6} \mathrm{H}_{5}, 4-\mathrm{Cl}, 2 \mathrm{NO}_{2}, 3,4,5-\mathrm{C}_{6} \mathrm{H}_{2}$,

3,4- $\left(\mathrm{OCH}_{3}\right)_{2}-\mathrm{C}_{6} \mathrm{H}_{3}$<smiles>N#CCc1c(NC([Mg])=S)[nH]c(=S)[nH]c1=O</smiles><smiles>[R]c1cccc(C2NC(=O)NC(C)=C2c2n[nH]c(=S)o2)c1</smiles><smiles>[R]c1cccc(C2NC(=O)NC(C)=C2C2=NNC([Y1])O2)c1</smiles>

$124 \mathrm{R}=\mathrm{H}, 4-\left(\mathrm{OCH}_{3}\right), 4-\mathrm{NO}_{2}$

$125 \mathrm{R}=\mathrm{H}, 4-\left(\mathrm{OCH}_{3}\right), \mathrm{Ar}=3,4-\left(\mathrm{NO}_{2}\right)_{2}-\mathrm{C}_{6} \mathrm{H}_{3}$

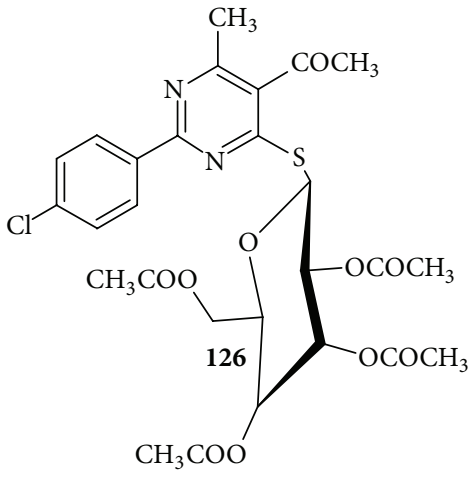<smiles>CC(=O)c1c(C)nc(-c2ccccc2)nc1SC1OC(CO)C(O)C1O</smiles><smiles>COC(=O)C[C@H]1O[C@H](Sc2nc(-c3ccc(CO)cc3)nc(C)c2C(C)=O)[C@H](OC(C)=O)[C@@H](OC(C)=O)[C@@H]1OC(C)=O</smiles>

FIGURE 16: Tetrasubstituted pyrimidine derivatives of antibacterial and antifungal activity. 
<smiles>Cc1nc(Cl)c(C#N)c(-c2ccncc2)n1</smiles>

129<smiles>[R]c1cccc(-c2nc(N)nc(O)c2C#N)c1</smiles><smiles>CC(c1ccc(F)c(F)c1F)C1C(=O)NC(=O)NC1=O</smiles>

132<smiles>COc1ccc(Nc2nc(=S)[nH]c(-c3ccccc3OC)c2C)cc1</smiles>

133<smiles>[X]C1=NC(c2c[nH]c3ccc([R])cc23)C(C(=O)OCC)=C(C)N1</smiles>

$134 \mathrm{R}=\mathrm{H}, \mathrm{Br}, \mathrm{Cl}$, I and $\mathrm{X}=\mathrm{O}, \mathrm{S}$<smiles>[R]SC1NC(=O)C=C(CCC)N1</smiles>

$135 \mathrm{R}=\mathrm{CH}_{3} \mathrm{C}_{6} \mathrm{H}_{11}$<smiles>CC1=C(C(=O)Cc2ccc(Cl)cc2)C(c2ccccc2)NC(=S)N1</smiles>

$137 \mathrm{R}=3,4-\left(\mathrm{OCH}_{3}\right), 2,4-\mathrm{OCH}_{3}$, $2-\mathrm{OCH}_{3}, 3-\mathrm{NO}_{2}, 3-\mathrm{OH}, 2-\mathrm{Cl}$<smiles>CCCC1=CC(=O)C(Cc2ccccc2)C(=S)N1</smiles>

136<smiles></smiles>

FIGURE 17: Tetrasubstituted pyrimidine derivatives of antibacterial and antifungal activity.

synthesized some new $N, N$-disubstituted dithiocarbamic acid 2-(6-arylhexahydropyrimidine-2,4-dione-3-yl) ethyl esters derivatives and evaluated their in vitro antibacterial activity against $S$. aureus, E. faecalis, E.coli, and $P$. aeruginosa and antifungal activity against C. albicans, Candida krusei, and Candida parapsilosis and found that the compound (149) having MIC value $16 \mu \mathrm{g}$ showed the most favourable antibacterial activity [162]. A few years later in 1997, Robson et al. synthesized novel 2,4-diamino-5-( $4^{\prime}$-benzylamino) and 2,4-diamino-5-[ $4^{\prime}$-N-methylbenzylamino)- $3^{\prime}$-nitrophenyl ]-6-ethylpyrimidines bearing 4-substituents on the benzylamino or N-methyl-benzylamino aryl ring and evaluated them for their antibacterial activity. Structure activity relationship study from the given data revealed that the compound (150) with the introduction of para substituent like $\mathrm{COOH}, \mathrm{CONH}_{2}, \mathrm{CONHMe}$, and $\mathrm{SO}_{2} \mathrm{NH}_{2}$ exhibited potent inhibitory activity against Toxoplasma gondii as compared to benzoprim or methylbenzoprim [163] (Figure 18).

Although chloropyrimidines appeared to have effective antimicrobial activity, Agrawal et al. synthesized some new derivatives containing aryl, heteroaryl, and alkylthio substituents at position 6 and also alkylthio substituents at position 2 because structure activity data of chloropyrimidine revealed that substitution at positions 2 and 6 has great influence on antitubercular activity; hence, synthesized derivatives were screened for in vitro antibacterial, antitubercular, and antifungal activities. The compound (151) with its various derivatives was found to display good antibacterial and antitubercular activity with MIC value $0.78 \mu \mathrm{g} / \mathrm{mL}$ and compound (152) demonstrated a good antifungal activity when 
<smiles>S=C1N=C(c2ccccc2)CC(c2cc3ccccc3n3nnnc23)N1</smiles>

139<smiles>S=C1N=C(c2ccc(Br)cc2)CC(c2cc3ccccc3n3nnnc23)N1</smiles>

140<smiles>[O]c1cccc(CC=C2C(=O)NC(=S)NC2=O)c1</smiles>

$141 \mathrm{R}=\mathrm{H}, \mathrm{CH}_{2} \mathrm{CH}_{2} \mathrm{OC}_{4} \mathrm{H}_{9}$<smiles>CCOC(=O)c1c(C)nc(-c2ccc(N(C)C)cc2)nc1-c1ccccc1</smiles><smiles>[Y19]C(=O)/C=C(/C([Y19])=[W])C1C(N)=NC(=S)N=C1N</smiles><smiles>NC1=NC(=S)N=C(N)C1/C(=C/S(=O)(=O)[Al])S(=O)(=O)[AlH2]</smiles>

$\mathrm{Ar}=\mathrm{C}_{6} \mathrm{H}_{5}, 4-\mathrm{Cl}-\mathrm{C}_{6} \mathrm{H}_{4}, 4-\mathrm{CH}_{3}-\mathrm{C}_{6} \mathrm{H}_{4}$

$142 \mathrm{R}=\mathrm{Br}, \mathrm{Cl}$<smiles>[R]c1cn2c(=O)[nH]c(=O)n2c2sc(CO)nc12</smiles><smiles>[R]c1cccc(C2NC(=S)NC(C)=C2C(=O)Nc2ccc(Cl)cc2)c1</smiles>

146<smiles>[R][X]c1ccccc1C1NC(=S)NC(C(C)C)=C1C(=O)Nc1ccc(Cl)cc1</smiles><smiles>[R]c1ccc2c(c1)nc(CC(C)C)n2C1C(CCCC)=NC(=S)N=C1CCCCC</smiles>

$148 \mathrm{R}=5-\mathrm{OCH}_{3}, 5 \mathrm{NO}_{2}, 5-\mathrm{Cl}$<smiles>O=C1CC(c2cccc(Cl)c2)=NC(=O)N1CCSC(=S)N1CCOCC1</smiles><smiles>[R]C(=O)c1ccc(CC([R])c2ccc(-c3c(N)nc(N)nc3CC)cc2[N+](=O)[O-])cc1</smiles>

$150 \mathrm{R}^{1}=\mathrm{H}, \mathrm{CH}_{3}$ and $\mathrm{R}^{2}=\mathrm{COOH}, \mathrm{CONHCH}_{3}, \mathrm{SO}_{2} \mathrm{NH}_{2}$

compared with the standard drug clotrimoxazole [36] (Figure 19).

In the hope of potent antifungal activity some pyrimidinone derivatives were synthesized and screened for in vitro antifungal activity and compound (153) demonstrated the significant activity against Phytophthora infestans and Colletotrichum falcatum with the introduction of chloro group [164]. A new series of 4(4' -bromophenyl)-6-substituted aryl1-acetylpyrimidine-2-thiol derivatives were synthesized and screened for the in vitro antimicrobial activity. The results showed that all the synthesized compounds (154) have shown significant, good to moderate antimicrobial activity due to the presence of thio group, which enhanced the respective activities with varied substituent groups, against selected pathogens [165]. Trantolo et al. synthesized a series of $\mathrm{N}^{6}$-substituted 6-aminopyrimidines and examined the effects of substituents governing the inhibition of DNA polymerase III from B. subtilis. The compounds (155) and
(156) having bromo and iodo substituents on position 5 of 6-(benzylamino) uracils and 6-p-toluidinouracils were equipotent with the parent compound [166]. However, Shivkumar et al. also reported some pyrimidinone derivatives and evaluated their in vitro antifungal activity. Results indicated that the compound (157) showed significant activity against C. albicans [167] (Figure 19).

A series of eleven 5-((E)-3-phenylacryloyl) pyrimidine2,4,6-(1H,3H,5H)-triones (5-acetyl pyrimidine 2,4,6$(1 \mathrm{H}, 3 \mathrm{H}, 5 \mathrm{H})$ trione based chalcones) were synthesized and screened for antibacterial and antifungal activities by Dhorajiya et al. Results revealed that compound (158) was comparable with the standard drug ciprofloxacin in case of $P$. aeruginosa [168]. For developing some new antimicrobial drugs, Elumalai et al. in the year of 2013 developed some new isoniazid cyclocondensed 1,2,3,4tetrahydropyrimidine derivatives and evaluated them for in vitro antimicrobial and antimycobacterial activities against 
<smiles>[R]Sc1nc([Al])c(C#N)c(Cl)n1</smiles>

151<smiles>CC1=C(c2nnc(S)s2)C(c2ccc(Cl)cc2)NC(=O)N1</smiles>

153

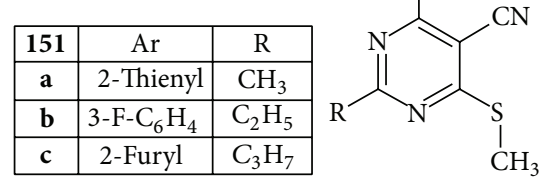

$152 \mathrm{R}=\mathrm{CH}_{3}, \mathrm{C}_{2} \mathrm{H}_{5}, \mathrm{CH}_{3}$<smiles>[R]c1cccc(C2C=C(c3ccc(Br)cc3)N=C(S)N2C(C)=O)c1</smiles>

\begin{tabular}{|c|c|}
\hline $\mathbf{1 5 4}$ & $\mathrm{R}$ \\
\hline $\mathbf{a}$ & $4-\mathrm{OCH}_{3}$ \\
\hline $\mathbf{b}$ & $3-\mathrm{OCH}_{3}$ \\
\hline $\mathbf{c}$ & $4-\mathrm{Cl}$ \\
\hline $\mathbf{d}$ & $2-\mathrm{Cl}$ \\
\hline $\mathbf{e}$ & $4-\mathrm{OH}$ \\
\hline $\mathbf{f}$ & $3-\mathrm{OH}$ \\
\hline $\mathbf{g}$ & $4-\mathrm{NO}_{2}$ \\
\hline $\mathbf{h}$ & $2-\mathrm{NO}_{2}$ \\
\hline $\mathbf{i}$ & $4-\mathrm{N}_{2}\left(\mathrm{CH}_{3}\right)_{2}$ \\
\hline $\mathbf{j}$ & $6-$ furyl \\
\hline $\mathbf{k}$ & $\mathrm{H}$ \\
\hline
\end{tabular}<smiles>[X]c1c(Nc2ccccc2)[nH]c(=O)[nH]c1=O</smiles><smiles>[X]c1c(NCc2ccccc2)[nH]c(=O)[nH]c1=O</smiles><smiles>[R]c1ccc(OCc2nnc(S)n2NC(=O)C2C(=O)N=C(C)NC2[Al])cc1</smiles>

$156 \mathrm{X}=\mathrm{Br}, \mathrm{I}, \mathrm{NO}_{2}$<smiles>[R]c1ccc(/C=C/C(=O)C2C(=O)NC(=O)NC2=O)cc1</smiles>

FIGURE 19: Tetrasubstituted pyrimidine derivatives of antibacterial and antifungal activity.

Bacillus subtilis, E. coli, Mycobacterium tuberculosis CIP, and $H_{37} R v$ strain. Exclusively studied SARs revealed that 1,2,3,4-tetrahydropyrimidines contain substituted phenyl and hetero aromatic rings responsible for antimicrobial and antimycobacterial activities. Substituted atom or group of atoms must be of strong electron withdrawing nature for potent activity because it decreases electron density in the ring due to inductive effect. Substitution of fluoride and chloride substitution at fourth and third positions of phenyl ring showed potent activity; also introduction of heterocyclic ring at fourth position showed moderate activity. Hence it was concluded that compound (159) was arguably the most potent when compared with current therapeutic agents norfloxacin and rifampicin because fluoride and chloride substituted phenyl ring present at 4 th position of 1,2,3,4-tetrahydropyrimidines enhancing the antimicrobial and antimycobacterial activities [169]. In the recent 2013, a series of pyrimidine bearing 1,3,4-oxadiazole derivatives have been synthesized and evaluated for antifungal activity against Candida albicans, Penicillium spp., and Aspergillus niger. It was found that compound (160) has shown promising antifungal activity at $10 \mu \mathrm{g} / \mathrm{mL}$ concentration when compared with the standard drug amphotericin-B [170] (Figure 19).

5.2. Antimycobacterial Activity of Pyrimidines. From the study of vast literature it was found that pyrimidine derivatives possessing antimycobacterial activity consist of only trisubstituted and tetrasubstituted pyrimidines derivatives.

5.2.1. Trisubstituted Pyrimidine Derivatives with Antimycobacterial Activity. Sohn et al. reported a paper in which around 100 anologues of sulfonylureas were screened for antimycobacterial activity against $M$. tuberculosis. The compound (161) was found to show comparable antimycobacterial activity with that of sulfometuron methyl inhibitor of acetohydroxyacid synthase (AHAS) and after demonstrated SAR information it was concluded that both 2-alkylcarbonyl and 2-hydroxyalkyl with 6-ethythio substituents at the aromatic 
<smiles>COc1cc(OC)nc(NC(=O)NS(=O)(=O)c2c(C(=O)C3CC3)cnn2C)n1</smiles>

161<smiles>COc1ccc(OC)c(Cc2cnc(N)nc2N)c1</smiles>

162<smiles>Nc1ncc(CC2C[C@@H]2Br)c(N)n1</smiles>

163<smiles>[R]c1cc(CN=Nc2ccc(C(=O)O)cc2)nc(O)n1</smiles><smiles>COc1ccc(CN(C)c2cc(-c3ccco3)ncn2)cc1</smiles>

165<smiles>COc1ccc(CN(C)c2cc(-c3ccco3)nc(Cl)n2)cc1</smiles>

$164 \mathrm{R}=2-\mathrm{NO}_{2}-\mathrm{C}_{6} \mathrm{H}_{4}, 3-\mathrm{NO}_{2}-\mathrm{C}_{6} \mathrm{H}_{4}, 4-\mathrm{OCH}_{3}-\mathrm{C}_{6} \mathrm{H}_{4}$<smiles>Nc1cc(-c2ccc(Cl)cc2)cc(-c2ccc(Cl)cc2)c1</smiles>

167<smiles>COc1ccc(/C=N/c2nc(-c3ccc(Cl)cc3)cc(-c3ccc([N+](=O)[O-])cc3)n2)cc1</smiles>

170<smiles>COc1ccc(-c2cc(N)cc(-c3ccc(Cl)cc3)c2)cc1</smiles>

168<smiles>COc1cc(/C=N/c2nc(-c3ccc(Cl)cc3)cc(-c3ccc([N+](=O)[O-])cc3)n2)cc(OC)c1OC</smiles>

171<smiles>COc1ccc(-c2cc(N)cc(-c3ccc(OC)cc3)c2)cc1</smiles><smiles>O=[N+]([O-])c1ccc(-c2cc(-c3ccc(Cl)cc3)nc(/N=C/c3ccc(Cl)cc3)n2)cc1</smiles>

172

FIGURE 20: Trisubstituted pyrimidine derivatives of antimycobacterial activity.

backbone might be a good scaffold in the sulfonylureas possessing potent activity [171]. 2,4-Diamino-5-[2-methoxy5-( $\omega$-carboxyalkoxy) benzyl] pyrimidines derivatives were synthesized by Rosowsky et al. and tested for their ability to inhibit partially purified foam P. carinii, T. gondii, and M. avium. $5^{\prime}-O-(\omega$-Carboxyalkyl) analogs were found to be the most potent and the compound (162) was found to be 245 times more potent than trimethoprim against Pc and 33fold higher than that of trimethoprim against Mycobacterium avium [172]. Also, 2,4-diamino-6-methylpyrimidine containing 5-(7,8-nido-dicarbaundecarboran-7-yl) methyl or 5-(1,2closo-dicabadodecarboran-1-yl) methyl substituents were synthesized and screened for their activity against $P$. carnii,
T. gondii, M. avium, M. tuberculosis, and Lactobacillus casei. The compound (163) was found to show 10 times greater activity [173]. Trivedi et al. carried out the synthesis of some new pyrimidines derivatives via a novel chalcone series and evaluated them for their antimycobacterial activities against M. tuberculosis $\mathrm{H}_{37} \mathrm{Rv}$. The compound (164) produced the highest efficacy and exhibited $>90 \%$ inhibition at $6.25 \mu \mathrm{g} / \mathrm{mL}$ due to the presence of 2-nitro, 3-nitro, and 4-methoxy substitution at phenyl ring added remarkable improvements in anti-tubercular activity [174] (Figure 20).

Pyrimidine analogs of antimycobacterial 6-aryl9-benzylpurines were synthesized by Read et al. and screened for their in vitro antibacterial activity 
against $M$. tuberculosis $\mathrm{H}_{37} \mathrm{Rv}$. Among the screened furylpyrimidines, the compounds having $\mathrm{N}$ methylbenzylamino group showed better activities and the compounds (165-166) were identified as the most active compounds having minimum inhibitory concentration of $3.0 \mu \mathrm{g} / \mathrm{mL}$ [175]. In another work, again some substituted pyrimidines were synthesized from chalcones by Umaa et al. and evaluated for their antitubercular potential and we found that three compounds (167-169) exhibited significant activity being equipotent with the standard drug [176]. A variety of novel 4-(4substituted phenyl)-6-(4-nitrophenyl)-2-substituted imino) pyrimidines were reported by Siddiqui et al. and we investigated their antiviral, antitubercular, and antibacterial activities. Results indicated that the pyrimidines with chloro and p-methoxyphenyl (170), trimethoxy (171) showed more potent activity than the reference drug and pyrimidines with chloro and chlorophenyl (172) and $p$ $\mathrm{N}$-dimethylaminophenyl substitutions showed equipotent activity in comparison with that of reference drugs [177] (Figure 20).

5.2.2. Tetrasubstituted Pyrimidine Derivatives Having Antimycobacterial Activity. N-Phenyl-6-methyl-2-oxo-4-phenyl-1, 2,3,4-tetrahydropyrimidines-5-carboxamides derivatives were synthesized by Virsodia et al. and evaluated for their antitubercular activity against Mycobacterium tuberculosis and we found that compounds (173) and (174) with 2,3-dimethylphenyl and 3,4-dimethyl carbomyl side chains, respectively, showed $65 \%$ and $63 \%$ inhibition; hence, presence of methyl groups on phenyl ring of C5 side chain with metasubstituted 4-phenyl was found to show good activity [178]. Srivastav et al. evaluated the antimycobacterial activities of 1(2-hydroxyethoxy)methyl-5-(1-azido-2-haloethyl or 1-azidovinyl) analogs and 1-[(2-hydroxy-1-(hydroxymethyl) ethoxy)methyl-5-decynyluracil and 1-[(2-hydroxy-1-(hydroxymethyl) ethoxy)methyl]-5-dodecynluracil against $M$. tuberculosis, Mycobacterium bovis, and Mycobacterium avium. It was found that 5-substituted acyclic pyrimidine compounds, that is, (175-177), were found to exhibit significant in vitro antimycobacterial activity [179] (Figure 21).

Srivastav et al. investigated the in vitro antimycobacterial activities of 5-alkyl, 5-alkynyl, furanopyrimidines, and 2' deoxynucleosides derivatives. It was found that compounds with 5-arylalkynyl substituents, that is, (178-180), displayed potent in vitro antitubercular activity against $M$. bovis and $M$. tuberculosis [180]. Johar et al. synthesized a series of $1-\beta$-D- $2^{\prime}$-arabinofuranosyl and $1-\left(2^{\prime}\right.$-dedoxy- $2^{\prime}$-fluoro- $\beta$-Dribofuransoyl) pyrimidine nucleosides possessing a diverse sets of alkenyl, alkyl, and halo substituents at the C-5 position of the uracil and investigated their effect on activity against $M$. tuberculosis, M. bovis, and M. avium. From a comprehensive overview and thorough study of SAR it is suggested that the compounds of 5-alkynyl series, that is, (181-183), showed the highest antimycobacterial potency which was similar or close to that of the rifampicin [181] (Figure 21).
5.3. Antimalarial Activity of Pyrimidines. Pyrimidine derivatives which were known to have antimalarial activity mainly consist of trisubstituted derivatives.

5.3.1. Trisubstituted Pyrimidine Derivatives of Antimalarial Activity. A series of 2,4,6 trisubstituted-pyrimidines (184) were synthesized and evaluated for their in vitro antimalarial activity. Out of total screened compounds, 14 compounds have shown in vitro antimalarial activity against Plasmodium falciparum with MIC in the range of $0.25-2 \mu \mathrm{g} / \mathrm{mL}$ and SAR study revealed that the substitution on phenyl ring shows an increased activity as substitution of methyl group at the para position of the compound represents a remarkable increase in activity [182]. The novel pyrimethamine and trimethoprim analogs were developed and tested for the in vitro antimalarial activities of synthesized compounds against $P$. falciparum. Pyrimethamine analogues (185) bearing $m$ $\mathrm{Cl}$ and unsubstituted 5-phenyl group together with long 6alkyl substituents and trimethoprim analogues (186) were 1025 times more effective than their parent compounds [183] (Figure 22).

Recently, the optimization studies of the 2-pyrimidine carbonitrile as lead series were done by Coterón et al. who studied the different heteroarylnitrile derivatives as potential falcipain inhibitors and therefore, potential antiparasitic lead compounds, with the 5-substituted-2-cyanopyrimidine chemical class emerging as the most potent and promising lead series. Results revealed that the introduction of a protonable amine in the structure of compound markedly improved the antiparasitic activity. The compounds (187-190) and derivatives of (191) presented excellent in vitro enzymatic activity and antiparasitic activity against $P$. falciparum [184] (Figure 22).

\subsection{Antileishmanial Activity of Pyrimidines}

5.4.1. Monosubstituted Pyrimidine Derivatives of Antileishmanial Activity. A series of compounds containing the nitrobenzene and sulfonamido moieties monosubstituted pyrimidine derivatives were synthesized and their leishmanicidal effect was assessed in vitro against $L$. infantum promastigotes. Among the evaluated compounds, the $p$ nitrobenzenesulfonamides (192) showed significant activity due to the presence of electron withdrawing nitro group [185] (Figure 23).

\subsubsection{Trisubstituted Pyrimidine Derivatives Possessing} Antileishmanial Activity. Some novel N- and O-substituted terpenyl trisubstituted pyrimidines derivatives were developed and screened for their in vitro antileishmanial activity profile in promastigote model by Chandra et al. The compound (193) with $p$-anisidino substitution showed $98.8 \%$ inhibition at a $1 \mu \mathrm{g} / \mathrm{mL}$ concentration, whereas with $\mathrm{OEt}$ and $\mathrm{OBu}$ substitution the same compound showed $99 \%$ inhibition at $5 \mu \mathrm{g} / \mathrm{mL}$ concentration [186]. A series of $[1,2,4]$ triazino[5,6-b]indol-3-ylthio-1,3,5triazines and pyrimidines derivatives were synthesized and screened for their in vitro antileishmanial activity 
<smiles>CCCCCOc1cccc(-c2nc(O)nc(C)c2C(=O)Cc2cccc(C)c2C)c1</smiles>

173<smiles>Cc1ccc(CC(=O)c2c(C)nc(O)nc2-c2cccc([N+](=O)[O-])c2)cc1C</smiles>

174<smiles>[X]CCCCCCCCCCCCCCCCCCO</smiles>

$175 \mathrm{X}=\mathrm{Br}, \mathrm{I}, \mathrm{Cl}$<smiles>CCC(CO)OCN1C=C(CC(C)(C)CC)C(=O)NC1C</smiles>

176<smiles>CCCCCC(C)(C)CC1=CN(COC(CC)CO)C(C)NC1=O</smiles>

177<smiles>O=c1[nH]c(=O)n(C2CC(O)C(CO)O2)cc1C#Cc1ccncc1</smiles>

178<smiles>NC1NC(=O)N(C2CC(O)C(CO)O2)C=C1C#Cc1cccnc1</smiles><smiles>[R]C#Cc1c[nH]c(=O)[nH]c1=O</smiles>

\begin{tabular}{|c|c|}
\hline $\mathbf{1 8 0}$ & $\mathrm{R}$ \\
\hline $\mathbf{a}$ & $\mathrm{C}_{6} \mathrm{H}_{5}$ \\
\hline $\mathbf{b}$ & $\mathrm{C}_{6} \mathrm{H}_{4}-n$-propyl \\
\hline $\mathbf{c}$ & $\mathrm{C}_{6} \mathrm{H}_{4}-n$-pentyl \\
\hline $\mathbf{d}$ & 2 -Pyridyl \\
\hline
\end{tabular}

179<smiles>CCCCCCCCCC#CC1=CN(C2CC(O)C(CO)O2)C(O)NC1=O</smiles>

181<smiles>CCCCCCCCCC#CC1=CN2C(O)C(CO)OC2C(O)C1F</smiles>

182<smiles>CCCCCCCCCC#CC1=CN(C2OC(CO)C(O)C2F)C(O)NC1=O</smiles>

183

FIGURE 21: Tetrasubstituted pyrimidine derivatives of antimycobacterial activity.

against Leishmania donovani. The pyrimidine derivatives (194) having piperidine at position 2 were found to show comparable activity against leishmaniasis with an $\mathrm{IC}_{50}$ of 4.01 and MIC of $20.54 \mu \mathrm{M}$ and to be the least toxic compounds which made them 20 - and 10 -fold more selective than that of the standard drugs pentamidine and stibogluconate [187]. A few years later in 1999, Chawdhury et al. synthesized compounds based on 5-benzyl-2,4-diaminopyrimidines and evaluated the compounds as inhibitors of leishmanial and trypanosomal dihydrofolate reductase. Results revealed that the compounds (195-197) were found to show good activity against Trypanosoma brucei, Trypanosoma cruzi and marginal activity against Leishmania infantum [188] (Figure 23).

5.5. In Vitro Antiamoebic Activity and Antiparsitic Activity of Pyrimidine. Praveen et al. synthesized a new series of 6ferrocenyl aryl 2-substituted pyrimidines and evaluated them for their in vitro antiamoebic activity against HMI:1MSS strain of Entamoeba histolytica. Out of 16 compounds, 10 compounds have methoxy substitution, thio group and chloro group exhibited higher antiamoebic activity than the reference drug metronidazole, and compound (198) was found to be most active and least toxic [189] (Figure 24).

Some new tetrasubstituted pyrimidine derivatives were developed as a new class of antifilarial agents as a series of 2-sulfonyl-6methyl-1,4-dihydropyrimidines were synthesized by Singh et al. and evaluated for their antifilarial activity against adult parasites of human lymphatic filarial parasites Brugia malayi in vitro at various concentrations. The compound (199) showed promising antifilarial activity [190] (Figure 24).

5.6. In Vitro Antiviral Activity of Pyrimidines. To study in vitro antiviral activity of various pyrimidine derivatives, we 


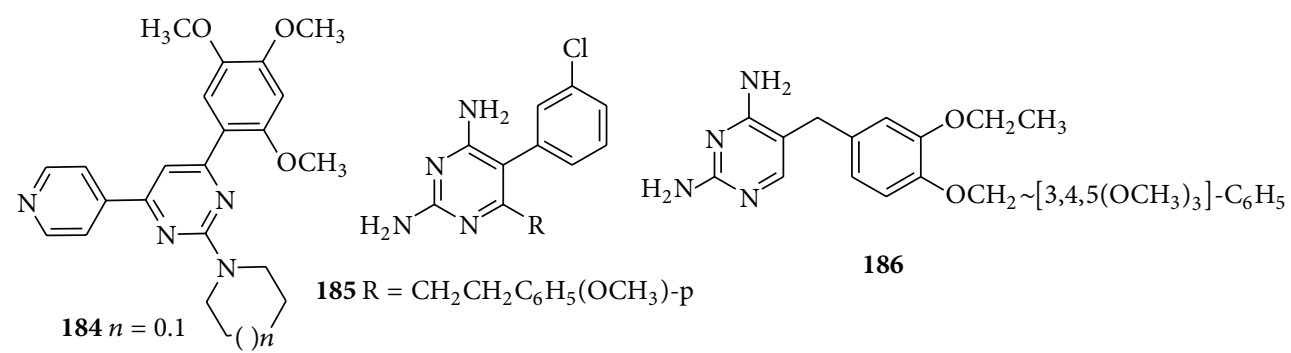<smiles>CC(C)CN(NC(=O)c1ccc(CN2CCN(C)CC2)cc1)c1nc(C#N)ncc1Br</smiles>

187<smiles>CN1CCN(Cc2ccc(C(=O)NN(CC3CCCC3)c3nc(C#N)ncc3Br)cc2)CC1</smiles>

188<smiles></smiles><smiles>CN1CCN(Cc2ccc(C(=O)NN(c3nc(C#N)ncc3Br)C3CCCCC3)cc2)CC1</smiles><smiles>[R]C(=O)NN(CC(C)C)c1nc(C#N)ncc1Br</smiles>

190

FIGURE 22: Trisubstituted pyrimidine derivatives possessing antimalarial activity.<smiles>O=[N+]([O-])c1ccc(S(=O)(=O)Nc2ncccn2)cc1</smiles>

192<smiles></smiles><smiles>[R]c1cc(C=CC2C(C)=CC=CC2(C)C)nc(C)n1</smiles>

$193 \mathrm{R}=\mathrm{OC}_{2} \mathrm{H}_{5}, \mathrm{OBu}$<smiles>CCOc1cccc(Cc2cnc(N)nc2N)c1</smiles>

$196 \mathrm{R}=\mathrm{C}_{2} \mathrm{H}_{5}, \mathrm{C}_{3} \mathrm{H}_{7}$<smiles>Cc1cc(Sc2nnc3c4ccccc4n(C)c3n2)nc(N2CCCCC2)n1</smiles>

194<smiles>[R]Oc1cccc(Cc2cnc(N)nc2N)c1</smiles>

FIGURE 23: Monosubstituted (192) and trisubstituted (193-197) pyrimidine derivatives having antileishmanial activity.

have classified the pyrimidine containing derivatives on the basis of substitution and this substitution is as follows.

5.6.1. Trisubstituted Pyrimidine Derivatives. With the view of potency of sulfonamides Selvam et al. synthesized the 4-[(1,2-dihydro-2-oxo-3H-indole-3-ylidene)amino $]-N$ (4,6- dimethyl-2-pyrimidinyl)-benzene sulfonamide derivatives and carried out anti-HIV assay on them and found that the compound (200) was more active against the replication of HIV-1 and HIV-2 in membrane type 4 [MT-4] [191]. The discovery in 2002 by Holý et al. showed 


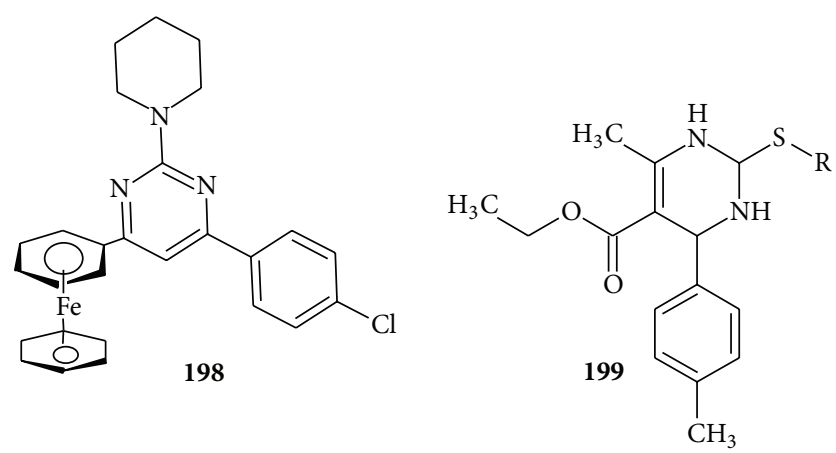

FIgURE 24: Trisubstituted pyrimidine derivatives with antiamoebic (198) and antiparasitic activity (199).

the antiviral activity of 6-[2-(Phosphonomethoxy) alkoxy] pyrimidines derivatives. Several analogues among the 6[2-(phosphonomethoxy)ethoxy] (PMEO] pyrimidines derivatives showed pronounced antiviral activity in cell culture and the derivatives that carry an amino group at C-2 of the pyrimidine ring, that is, (201) and (202), emerged as the most potent compounds [192] (Figure 25).

5.6.2. Tetrasubstituted Pyrimidines Derivatives. Sriram et al. designed the aminopyrimidinimino istain derivatives as a novel nonnucleosidase reverse transcriptase inhibitor with broad-spectrum chemotherapeutic properties for the effective treatment of AIDS (Figure S2). The compounds (203) and (204) with their different derivatives like ciprofloxacin moiety and lomefloxacin moiety at N-1 position emerged as the most potent broad-spectrum chemotherapeutic agent active against HIV, HCV, M. tuberculosis, and various pathogenic bacteria [193]. In the early 1999, the novel potent and selective dihydro-alkoxy-benzyl-oxypyrimidine derivatives, namely, 5-alkyl-2-(thio)-2,6-(-diphenylmethyl)3,4-dihydropyrimidine-4(3H)-ones derivatives, were synthesized and tested as anti-HIV agent in both cell based and enzyme based assays. Result revealed that the compounds having 6-(2,6-difluorophenylmethyl) substituents (205) were found to be most potent significantly higher than that of nevirapine with $\mathrm{EC}_{50}$ 's ranging between 40 and $90 \mu \mathrm{M}$ [194]. 2,4Diamino-5-cyano-6-\{[(diisopropoxyphosphoryl) methoxy] ethoxy\} pyrimidines derivatives (206) were synthesized by Hocková et al. and evaluated for their in vitro antiviral activity and they found that 5-cyano and 5-formyl derivatives showed remarkable activity against herpes simplex virus type 1 or type 2, cytomegalovirus, and vaccinia virus with inhibitory concentration of $0.0027-0.011 \mu \mathrm{mol} / \mathrm{mL}$ [195] (Figure 26).

A subsequent paper has been reviewed on antiviral activity in which Mohamed et al. prepared the 2-(2,4dioxopentan-3-ylthio)-1,6-dihydro-4-(1,2,34-tetrahydronapthalen-6-yl)-6-(3,4-dimethoxyphenyl)pyrimidin-5(4H)-one derivatives and screened them for their in vitro antiviral activity and compound (207) was found to have good antiviral activity with $90 \%$ inhibition; hence, it was considered to be highly promising compound by confirming and comparing its activity with the antiviral activity of acyclovir [196]. A series of dihydro-alkylthio-benzyloxopyrimidines were synthesized by Nawrozkij et al. who evaluated the compounds for their in vitro antiviral activity. The compound (208) with 2,6-dichloro-, 2chloro-6-fluoro-, and 2,6-difluoro-benzyl substitution at C-6 and ethyl, iso-propyl at C-5 was found to be the most potent derivatives due to its capability to inhibit the HIV-1 strain by 50\% [197]. A novel and new class of the dihydroxypyrimidinecarboxylic acid derivatives and corresponding N-methylpyrimidinone were prepared by Summa et al. and tested in the HCV replicon assay. The compound (209) having the desired phenolic function in the meta position was found to be the most active having $\mathrm{IC}_{50}$ of $5.8 \mu \mathrm{M}$ [198]. Another paper reported the 2-(2thienyl)-5,6-dihydroxy-4-carboxypyrimidines derivatives which were screened as inhibitors of the hepatitis $C$ virus NS5B and the compound (210) showed the best cell based activity which was 60-fold much better than enzyme based assay and showed no cytotoxicity up to $100 \mu \mathrm{M}$ [199]. Manetti et al. carried out the parallel solution phase and microwave-assisted synthesis of dihydroxy-alkoxybenzyl-oxypyrimidines (DABOs) and screened them for their antiviral activity toward both the highly purified recombinant human immunodeficiency virus type 1 (HIV-1) reverse transcriptase (RT) enzyme (wild-type and mutants) and wild-type (wt) and mutant HIV-1 strains. Results from anti-HIV reverse transcriptase assay and anti-HIV activity in lymphoid cells revealed that compound (211) had an antiHIV profile comparable to that of nevirapine and efavirenz [200]. Novel C-6 fluorinated acyclic side chain pyrimidine derivatives were synthesized by Prekupec et al. and evaluated for their in vitro antiviral activity against cytomegalovirus $\left(\mathrm{CMV}^{\mathrm{a}} \mathrm{AD}-169\right.$ and Davis strain) in human embryonic lung (HEL) cells; Varicella-zoster virus, parainfluenza virus-3, retrovirus-1, Sindbis, and Punta Toro virus in vero cell. The 5-bromopyrimidine derivatives (212) and (213) showed the highest activity [201] (Figure 26).

\section{Conclusion}

As a result of vigorous research and vast literature survey, the dogma laid down by chemistry of pyrimidines has engendered long considerable interest which makes them occupy a very distinct and unique place in our lives. From the above review it was concluded that the trisubstituted and tetrasubstituted pyrimidines containing electron withdrawing group like nitro on the phenyl ring were found to show more potent in vitro antimicrobial activity as compared to the chloro or methoxy group. This offers the medicinal chemist continued interest in pyrimidine moiety in drug development against microbes. It will also ensure the development of reliable methods for the construction of important area of research in heterocyclic chemistry.

\section{Abbreviations}

MRSA: Methicillin-resistant Staphylococcus aureus

DHFR: Dihydrofolate reductase

AIDS: Acquired Immune Deficiency Syndrome 
<smiles>[R]c1ccc2c(c1)/C(=N/c1ccc(S(=O)(=O)Nc3nc(C)cc(C)n3)cc1)C(=O)N2</smiles>

$200 \mathrm{R}=\mathrm{H}, \mathrm{COCH}_{3}$<smiles>Nc1cc(OCCOPOO)nc(N)n1</smiles>

201<smiles>COPOCCOc1cc(O)nc(C)n1</smiles>

202

FIgURE 25: Trisubstituted pyrimidine derivatives of antiviral activity.<smiles>COc1cc(Cc2cnc(/N=C3\C(=O)N(CN4CCOCC4)c4ccc(Br)cc43)nc2N)cc(OC)c1OC</smiles><smiles>COc1cc(Cc2cnc(N=C3C(=O)N(CN4CCN(c5c(F)cc6c(=O)c(C(=O)O)c[nH]c6c5F)CC4C)c4ccc(Br)cc43)nc2N)cc(OC)c1OC</smiles><smiles>[R]C1C(=O)N=C(SC(C)C)N=C1Cc1c(F)cccc1F</smiles>

$205 \mathrm{R}=\mathrm{H}, \mathrm{Me}$<smiles>[R]c1c(N)nc(N)nc1OCCOCP(=O)(O)O</smiles>

$206 \mathrm{R}=\mathrm{H}, \mathrm{Me}$<smiles>COc1ccc(C2NC(SC(C(C)=O)C(C)=O)=NC(c3ccc4c(c3)CCCC4)C2=O)cc1OC</smiles>

207<smiles>Cc1cccc(Cl)c1CNC(=O)Nc1ccsc1-c1nc(O)c(O)c(C(=O)O)n1</smiles>

210<smiles>COc1ccc(CCSc2nc(Cc3c(Cl)cccc3Cl)c(C)c(=O)[nH]2)cc1</smiles><smiles>COc1nc(CBr)c(Br)c(OC)n1</smiles><smiles>COc1nc(OC)c(Br)c(C(Br)Br)n1</smiles>

FIGURE 26: Trisubstituted pyrimidine derivatives of antiviral activity.

IDU: 5-Iodo-2'-deoxyuridine

CMV: Cytomegalovirus

SBT: S-Benzyl isothiouronium chloride

MIC: Minimum inhibitory concentration

DABOs: Dihydroxy alkoxy-benzyloxy pyrimidines

HIV-1: Human deficiency virus type 1

HEL: Human embryonic lung cells

RT: $\quad$ Reverse transcriptase.

\section{Conflict of Interests}

The authors have no relevant affiliations or financial involvement with any organization or entity with a financial interest in or financial conflict with the subject matter or materials discussed in the paper. This includes employment, consultancies, honoraria, stock ownership or options, expert testimony, grants or patents received or pending, or royalties. No writing assistance was utilized for writing this paper. 


\section{Acknowledgments}

The authors are thankful to the Department of Pharmaceutical Sciences, Kurukshetra University, Haryana, India, and Bioinformatics Centre, Biotech Park, Lucknow, Uttar Pradesh, India, for providing the necessary help to complete the paper.

\section{References}

[1] Infectious Society of America, Statement of the IDSA Concerning "Bioshield II: Responding to an Diseases Ever-Changing Threat", IDSA, Alexandria, Va, USA, 2004.

[2] J. S. Bradley, R. Guidos, S. Baragona et al., "Anti-infective research and development-problems, challenges, and solutions," The Lancet Infectious Diseases, vol. 7, no. 1, pp. 68-78, 2007.

[3] A. L. Panlilio, D. H. Culver, R. P. Gaynes et al., "Methicillinresistant Staphylococcus aureus in U.S. hospitals, 1975-1991," Infection Control and Hospital Epidemiology, vol. 13, no. 10, pp. 582-586, 1992.

[4] J. Davies, "Origins and evolution of antibiotic resistance," Microbiologia, vol. 12, no. 1, pp. 9-16, 1996.

[5] A. D. Russell, "Mechanisms of bacterial insusceptibility to biocides," The American Journal of Infection Control, vol. 29, no. 4, pp. 259-261, 2001.

[6] H. P. Schweizer, "Triclosan: a widely used biocide and its link to antibiotics," FEMS Microbiology Letters, vol. 202, no. 1, pp. 1-7, 2001.

[7] S. B. Levy, "Antibiotic and antiseptic resistance: impact on public health," Pediatric Infectious Disease Journal, vol. 19, no. 10, pp. S120-S122, 2000.

[8] S. B. Levy, "Active efflux, a common mechanism for biocide and antibiotic resistance," Journal of Applied Microbiology, vol. 92, no. 1, pp. 65S-71S, 2002.

[9] K. Poole, "Mechanisms of bacterial biocide and antibiotic resistance," Journal of Applied Microbiology, vol. 92, no. 1, pp. 55S-64S, 2002.

[10] M. Hassan, D. van der Lelie, D. Springael, U. Römling, N. Ahmed, and M. Mergeay, "Identification of a gene cluster, CZR, involved in cadmium and zinc resistance in Pseudomonas aeruginosa," Gene, vol. 238, no. 2, pp. 417-425, 1999.

[11] S. A. Lerner, "Clinical impact of antibiotic resistance," Advances in Experimental Medicine and Biology, vol. 456, pp. 7-15, 1998.

[12] D. M. Livermore, "Epidemiology of antibiotic resistance," Intensive Care Medicine, vol. 26, Supplement 1, pp. S14-S21, 2000.

[13] L. Jeu, F. J. Piacenti, A. G. Lyakhovetskiy, and H. B. Fung, "Voriconazole," Clinical Therapeutics, vol. 25, no. 5, pp. 13211381, 2003.

[14] E. de Clercq, "New developments in anti-HIV chemotherapy," Il Farmaco, vol. 56, no. 1-2, pp. 3-12, 2001.

[15] K. Poole, "Overcoming antimicrobial resistance by targeting resistance mechanisms," Journal of Pharmacy and Pharmacology, vol. 53, no. 3, pp. 283-294, 2001.

[16] P. W. Taylor, P. D. Stapleton, and J. P. Luzio, "New ways to treat bacterial infections," Drug Discovery Today, vol. 7, no. 21, pp. 1086-1091, 2002.

[17] A. R. M. Coates and Y. Hu, "Novel approaches to developing new antibiotics for bacterial infections," The British Journal of Pharmacology, vol. 152, no. 8, pp. 1147-1154, 2007.
[18] D. W. Kimberlin and R. J. Whitley, "Antiviral resistance: mechanisms, clinical significance, and future implications," Journal of Antimicrobial Chemotherapy, vol. 37, no. 3, pp. 403-421, 1996.

[19] Y. Ju and R. S. Varma, "Aqueous N-heterocyclization of primary amines and hydrazines with dihalides: microwave-assisted syntheses of $N$-azacycloalkanes, isoindole, pyrazole, pyrazolidine, and phthalazine derivatives," Journal of Organic Chemistry, vol. 71, no. 1, pp. 135-141, 2006.

[20] Y. Ju, D. Kumar, and R. S. Varma, "Revisiting nucleophilic substitution reactions: microwave-assisted synthesis of azides, thiocyanates, and sulfones in an aqueous medium," Journal of Organic Chemistry, vol. 71, no. 17, pp. 6697-6700, 2006.

[21] P. D. Lokhande, B. Y. Waghamare, and S. S. Sakate, "Regioselective one-pot synthesis of 3,5-diarylpyrazoles," Indian Journal of Chemistry B, vol. 44, no. 11, pp. 2338-2342, 2005.

[22] G. J. Reddy, D. Manjula, K. S. Rao, M. Khalilullah, and D. Latha, "A Direct single step synthesis of 1,3-diaryl-4-cyanopyrazoles and their conversion to 1,3-diaryl-4-(4,6-diamino 1,3,5-triazin2-yl)pyrazoles," Indian Journal of Chemistry B, vol. 44, pp. 2412$2415,2005$.

[23] C. A. Zificsak and D. J. Hlasta, "Current methods for the synthesis of 2-substituted azoles," Tetrahedron, vol. 60, no. 41, pp. 8991-9016, 2004.

[24] T. Haino, M. Tanaka, K. Ideta, K. Kubo, A. Mori, and Y. Fukazawa, "Solid-phase synthesis of liquid crystalline isoxazole library," Tetrahedron Letters, vol. 45, no. 11, pp. 2277-2279, 2004.

[25] M. García-Valverde and T. Torroba, "Special issue: sulfurnitrogen heterocycles," Molecules, vol. 10, no. 2, pp. 318-320, 2005.

[26] D. W. Hopper, A. L. Crombie, J. J. Clemens, and S. Kwon, "Six-membered ring systems: pyridine and benzo derivatives," Progress in Heterocyclic Chemistry, vol. 21, pp. 330-374, 2009.

[27] A. Manlove and M. P. Groziak, "Six-membered ring systems: diazines and benzo derivatives," Progress in Heterocyclic Chemistry, vol. 21, pp. 375-414, 2009.

[28] D. J. Brown, Comprehensive Heterocyclic Chemistry, vol. 14, Pergamon Press, Oxford, UK, 1984, edited by A. R. Katritzky and C. W. Rees.

[29] R. C. Elderfield, Heterocyclic Compounds, vol. 6, John Wiley \& Sons, New York, NY, USA, 1957.

[30] P. Y. Bruice, Organic Chemistry, Pearson Education, Singapore, 3rd edition, 2007.

[31] A. E. A. Porter, Diazines and Benzodiazines, vol. 14, Pregamon Press, Elsevier Science BV, Amsterdam, The Netherlands, 1979.

[32] C. O. Kappe, "100 years of the biginelli dihydropyrimidine synthesis," Tetrahedron, vol. 49, no. 32, pp. 6937-6963, 1993.

[33] P. Sharma, N. Rane, and V. K. Gurram, "Synthesis and QSAR studies of pyrimido[4,5-d]pyrimidine-2,5-dione derivatives as potential antimicrobial agents," Bioorganic and Medicinal Chemistry Letters, vol. 14, no. 16, pp. 4185-4190, 2004.

[34] O. Prakash, V. Bhardwaj, R. Kumar, P. Tyagi, and K. R. Aneja, "Organoiodine (III) mediated synthesis of 3-aryl/hetryl5,7-dimethyl-1,2,4-triazolo[4,3-a]pyrimidines as antibacterial agents," European Journal of Medicinal Chemistry, vol. 39, no. 12, pp. 1073-1077, 2004.

[35] M. Botta, M. Artico, S. Massa et al., "Synthesis, antimicrobial and antiviral activities of isotrimethoprim and some related derivatives," European Journal of Medicinal Chemistry, vol. 27, no. 3, pp. 251-257, 1992.

[36] N. Agarwal, P. Srivastava, S. K. Raghuwanshi et al., "Chloropyrimidines as a new class of antimicrobial agents," Bioorganic and Medicinal Chemistry, vol. 10, no. 4, pp. 869-874, 2002. 
[37] B. Roth and B. S. Rauckman, "2,4-Diamino-5-(1,2,3,4tetrahydro-(substituted or unsubstituted)-6-quinolylmethyl)pyrimidines, useful as antimicrobials," U.S. Patent 4, 587, 341, 1986.

[38] S. Marquais-Bienewald, W. Holzol, A. Preuss, and A. Mehlin, "Use of substituted 2,4-bis (alkylamino) pyrimidines," U.S. Patent, 0188453 A1, 2006.

[39] S. M. Daluge, P. Skonezny, B. Roth, and B. S. Raukman, "2,4Diamino-5-(substituted) pyrimidine, useful as antimicrobials," U.S. Patent 4, 590, 271, 1986.

[40] S. Ito, K. Masuda, S. Kusano et al., "Pyrimidine derivative, process for preparing same and agricultural or horticultural fungicidal composition containing same," U.S. Patent 4, 988, 704, 1991.

[41] Y. Nakagawa, S. Bobrov, C. R. Semer, T. A. Kucharek, and M. Harmoto, "Fungicidal pyrimidine derivatives," U.S. Patent 6, 818, 631 B1, 2004.

[42] N. Agarwal, S. K. Raghuwanshi, D. N. Upadhyay, P. K. Shukla, and V. J. Ram, "Suitably functionalised pyrimidines as potential antimycotic agents," Bioorganic and Medicinal Chemistry Letters, vol. 10, no. 8, pp. 703-706, 2000.

[43] H. S. Basavaraja, G. M. Sreenivasa, and E. Jayachandran, "Synthesis and biological activity of novel pyrimidino imidazolines," Indian Journal of Heterocyclic Chemistry, vol. 15, p. 69, 2005.

[44] V. J. Ram, N. Haque, and P. Y. Guru, "Chemotherapeutic agents XXV: synthesis and leishmanicidal activity of carbazolylpyrimidines," European Journal of Medicinal Chemistry, vol. 27, no. 8, pp. 851-855, 1992.

[45] M. Amir, S. A. Javed, and H. Kumar, "Pyrimidine as antiinflammatory agent: a review," Indian Journal of Pharmaceutical Sciences, vol. 68, p. 337, 2007.

[46] S. M. Sondhi, S. Jain, A. D. Dwivedi, R. Shukla, and R. Raghubir, "Synthesis of condensed pyrimidines and their evaluation for anti-inflammatory and analgesic activities," Indian Journal of Chemistry B, vol. 47, no. 1, pp. 136-143, 2008.

[47] S. Vega, J. Alonso, J. A. Diaz, and F. Junquera, "Synthesis of 3substituted-4-phenyl-2-thioxo-1,2,3,4,5,6,7,8-octahydrobenzo [4,5] thieno[2,3-d]pyrimidines," Journal of Heterocyclic Chemistry, vol. 27, no. 2, pp. 269-273, 1990.

[48] D. R. Hannah and M. F. G. Stevens, "Structural studies on bioactive compounds-part 38.1: reactions of 5aminoimidazole-4-carboxamide: synthesis of imidazo[1,5a]quinazoline-3-carboxamides," Journal of Chemical Research S, no. 7, pp. 398-401, 2003.

[49] K. Rana, B. Kaur, and B. Kumar, "Synthesis and antihypertensive activity of some dihydropyrimidines," Indian Journal of Chemistry B, vol. 43, no. 7, pp. 1553-1557, 2004.

[50] P. A. S. Smith and R. O. Kan, "Cyclization of isothiocyanates as a route to phthalic and homophthalic acid derivatives," Journal of Organic Chemistry, vol. 29, no. 8, pp. 2261-2265, 1964.

[51] J. Balzarini and C. McGuigan, "Bicyclic pyrimidine nucleoside analogues (BCNAs) as highly selective and potent inhibitors of varicella-zoster virus replication," Journal of Antimicrobial Chemotherapy, vol. 50, no. 1, pp. 5-9, 2002.

[52] R. W. von Borstel, "Treatment of chemotherapeutic agent and antiviral agent toxicity with acylated pyrimidine nucleosides," U.S. Patent 6, 344, 447 B2, 2002.

[53] R. Storer, A. Moussa, P. La Colla, and M. Artico, "Oxopyrimidine compounds," U.S. Patent, 0014774 Al, 2005.

[54] H. W. Lee, Y. K. Bok, B. A. Joong et al., "Molecular design, synthesis, and hypoglycemic and hypolipidemic activities of novel pyrimidine derivatives having thiazolidinedione," European Journal of Medicinal Chemistry, vol. 40, no. 9, pp. 862-874, 2005.

[55] P. F. Juby, T. W. Hudyma, M. Brown, J. M. Essery, and R. A. Partyka, "Antiallergy agents. 1. 1,6-dihydro-6-oxo-2phenylpyrimidine-5-carboxylic acids and esters," Journal of Medicinal Chemistry, vol. 22, no. 3, pp. 263-269, 1979.

[56] A. K. Gupta, Sanjay, H. P. Kayath, A. Singh, G. Sharma, and K. C. Mishra, "Anticonvulsant activity of pyrimidine thiols," Indian Journal of Pharmacology, vol. 26, no. 3, pp. 227-228, 1994.

[57] A. A. Abu-Hashem, M. M. Youssef, and H. A. R. Hussein, "Synthesis, antioxidant, antituomer activities of some new thiazolopyrimidines, pyrrolothiazolopyrimidines and triazolopyrrolothiazolopyrimidines derivatives," Journal of the Chinese Chemical Society, vol. 58, no. 1, pp. 41-48, 2011.

[58] A. A. Abu-Hashem, M. F. El-Shehry, and F. A. Badria, "Design and synthesis of novel thiophenecarbohydrazide, thienopyrazole and thienopyrimidine derivatives as antioxidant and antitumor agents," Acta Pharmaceutica, vol. 60, no. 3, pp. 311323, 2010.

[59] S. A. Rahaman, Y. R. Pasad, P. Kumar, and B. Kumar, "Synthesis and anti-histaminic activity of some novel pyrimidines," Saudi Pharmaceutical Journal, vol. 17, no. 3, pp. 255-258, 2009.

[60] Y. Nezu, M. Miyazaki, K. Sugiyama, and I. Kajiwara, "Dimethoxypyrimidine as novel herbicides-part 1: synthesis and herbicidal activity of dimethoxyphenoxyphenoxypyrimidines and analogues," Pesticide Science, vol. 47, pp. 103-113, 1996.

[61] J. W. Coe, A. F. J. Fliri, T. Kaneko, and E. R. Larson, "Pyrimidine derivatives enhancing antitumour activity," U.S. Patent 5, 491, 234, 1996.

[62] G. A. Breault, N. J. Newcombe, and A. P. Thomas, "Imidazolo5-YL-2-anilino-pyrimidines as agents for the inhibition of the cell proliferation," U.S. Patent 6, 969, 714 B2, 2005.

[63] F. Xie, H. Zhao, L. Zhao, L. Lou, and Y. Hu, "Synthesis and biological evaluation of novel 2,4,5-substituted pyrimidine derivatives for anticancer activity," Bioorganic and Medicinal Chemistry Letters, vol. 19, no. 1, pp. 275-278, 2009.

[64] M. A. Kaldrikyan, L. A. Grigoryan, V. A. Geboyan, F. G. Arsenyan, G. M. Stepanyan, and B. T. Garibdzhanyan, "Synthesis and antitumor activity of some disubstituted 5-(3-methyl-4alkoxybenzyl)pyrimidines," Pharmaceutical Chemistry Journal, vol. 34, no. 10, pp. 521-524, 2000.

[65] A. L. S. Rodrigues, J. M. Rosa, V. M. Gadotti et al., "Antidepressant-like and antinociceptive-like actions of 4-(4" chlorophenyl)-6-(4" -methylphenyl)-2-hydrazinepyrimidine Mannich base in mice," Pharmacology Biochemistry and Behavior, vol. 82, no. 1, pp. 156-162, 2005.

[66] J. Tani, Y. Yamada, T. Oine, T. Ochiai, R. Ishida, and I. Inoue, "Studies on biologically active halogenated compounds. 1. Synthesis and central nervous system depressant activity of 2-(fluoromethyl)-3-aryl-4(3H)-quinazolinone derivatives," Journal of Medicinal Chemistry, vol. 22, no. 1, pp. 95-99, 1979.

[67] B. Kumar, B. Kaur, J. Kaur, A. Parmar, R. D. Anand, and H. Kumar, "Thermal/microwave assisted synthesis of substituted tetrahydropyrimidines as potent calcium channel blockers," Indian Journal of Chemistry B, vol. 41, no. 7, pp. 1526-1530, 2002.

[68] K. S. Jain, T. S. Chitre, P. B. Miniyar et al., "Biological and medicinal significance of pyrimidines," Current Science, vol. 90, no. 6 , pp. 793-803, 2006. 
[69] G. H. Hitchings, G. B. Elion, H. Vanderwerff, and E. A. Falco, "Pyrimidine derivatives as antagonists of pteroylglutamic acid," The Journal of Biological Chemistry, vol. 174, no. 2, pp. 765-766, 1948.

[70] S. Futterman, "Enzymatic reduction of folic acid and dihydrofolic acid to tetrahydrofolic acid," The Journal of Biological Chemistry, vol. 228, no. 2, pp. 1031-1038, 1957.

[71] W. C. Werkheiser, "Specific binding of 4-amino folic acid analogues by folic acid reductase," The Journal of Biological Chemistry, vol. 236, no. 3, pp. 888-893, 1961.

[72] I. Kompis and A. Wick, "Synthese von 4-halogensubstituierten analogen von trimethoprim," Helvetica Chimica Acta, vol. 60, no. 8, pp. 3025-3034, 1977.

[73] S. Hawser, S. Lociuro, and K. Islam, "Dihydrofolate reductase inhibitors as antibacterial agents," Biochemical Pharmacology, vol. 71, no. 7, pp. 941-948, 2006.

[74] P. Schneider, S. Hawser, and K. Islam, "Iclaprim, a novel diaminopyrimidine with potent activity on trimethoprim sensitive and resistant bacteria," Bioorganic and Medicinal Chemistry Letters, vol. 13, no. 23, pp. 4217-4221, 2003.

[75] C. C. Cheng and B. Roth, "6 recent progress in the medicinal chemistry of 2,4-diaminopyrimidines," Progress in Medicinal Chemistry, vol. 19, pp. 269-331, 1982.

[76] J. Hughes, L. C. Roberts, and A. J. Coppridge, "Sulfacytine: a new sulfonamide, double blind comparison with sulfisoxazole in acute uncomplicated urinary tract infections," Journal of Urology, vol. 114, no. 6, pp. 912-914, 1975.

[77] N. J. White, "The treatment of malaria," The New England Journal of Medicine, vol. 335, no. 11, pp. 800-806, 1996.

[78] I. Von Zabern, R. Nolte, H. Przyklenk, and W. Vogt, "Effect of different sulfonamides on the human serum complement system," International Archives of Allergy and Applied Immunology, vol. 76, no. 3, pp. 205-213, 1985.

[79] M. E. Stolar, "Synergistic antibacterial composition," U.S. Patent 4, 470, 978, 1984.

[80] A. Carr, R. Penny, and D. A. Cooper, "Efficacy and safety of rechallenge with low-dose trimethoprim-sulphamethoxazole in previously hypersensitive HIV-infected patients," AIDS, vol. 7, no. 1, pp. 65-71, 1993.

[81] J. J. Reddick, S. Saha, J. Lee, J. S. Melnick, J. Perkins, and T. P. Begley, "The mechanism of action of bacimethrin, a naturally occurring thiamin antimetabolite," Bioorganic and Medicinal Chemistry Letters, vol. 11, no. 17, pp. 2245-2248, 2001.

[82] P. Singh, R. Kumar, and B. K. Sharma, "Quantitative structureactivity relationship study of 5-iodo- and diaryl-analogues of tubercidin: inhibitors of adenosine kinase," Journal of Enzyme Inhibition and Medicinal Chemistry, vol. 18, no. 5, pp. 395-402, 2003.

[83] L. P. G. Wakelin and M. J. Waring, Comprehensive Medicinal Chemistry, Drug Compendium, vol. 2, Pergamon Press, Oxford, UK, 1990, edited by P. G. Sammers.

[84] E. de Clercq, "Antiviral drugs in current clinical use," Journal of Clinical Virology, vol. 30, no. 2, pp. 115-133, 2004.

[85] H. Mitsuya, K. J. Weinhold, and P. A. Furman, “ 3 '-Azido-3' deoxythymidine (BW A509U): an antiviral agent that inhibits the infectivity and cytopathic effect of human T-lymphotropic virus type III/lymphadenopathy-associated virus in vitro," Proceedings of the National Academy of Sciences of the United States of America, vol. 82, no. 20, pp. 7096-7100, 1985.

[86] R. van Leeuwen, C. Katlama, V. Kitchen et al., "Evaluation of safety and efficacy of 3TC (lamivudine) in patients with asymptomatic or mildly symptomatic human immunodeficiency virus infection: a phase I/II study," Journal of Infectious Diseases, vol. 171, no. 5, pp. 1166-1171, 1995.

[87] H. Mitsuya, "Anti-HIV nucleosides: past, present and future," Journal of Immunoassay, vol. 18, no. 3, pp. 285-287, 1997.

[88] P. M. Woster, Foye's Principles of Medicinal Chemistry, Lippincott Williams \& Wilkins, Wolters Kluwar Business, Philadelphia, Pa, USA, 6th edition, 2008.

[89] J. Smith and D. Andes, "Therapeutic drug monitoring of antifungals: pharmacokinetic and pharmacodynamic considerations," Therapeutic Drug Monitoring, vol. 30, no. 2, pp. 167-172, 2008.

[90] B. Chadwick, M. Addy, and D. M. Walker, "Hexetidine mouthrinse in the management of minor aphthous ulceration and as an adjunct to oral hygiene," The British Dental Journal, vol. 171, no. 3-4, pp. 83-87, 1991.

[91] M. Butters, J. Ebbs, S. P. Green et al., "Process development of voriconazole: a novel broad-spectrum triazole antifungal agent," Organic Process Research and Development, vol. 5, no. 1, pp. 28-36, 2001.

[92] R. Gage and D. A. Stopher, "A rapid HPLC assay for voriconazole in human plasma," Journal of Pharmaceutical and Biomedical Analysis, vol. 17, no. 8, pp. 1449-1453, 1998.

[93] V. K. Kapoor and H. Singh, Medicinal and Pharmaceutical Chemistry, edited by M. K. Jain, Vallabh Prakashan, Delhi, India, 2nd edition, 2005.

[94] N. V. Kolotova, V. O. Koz'minykh, A. V. Dolzhenko et al., "Substituted amides and hydrazides of dicarboxylic acids. Part 9. Pharmacological activity of the products of interaction of 2aminopyridines and 2-aminopyrimidine with dicarboxylic acid anhydrides," Pharmaceutical Chemistry Journal, vol. 35, no. 3, pp. 146-150, 2001.

[95] T. Govindasami, A. Pandey, N. Palanivelu, and A. Pandey, "Synthesis, characterization and antibacterial activity of biologically important vanillin related hydrazone derivatives," International Journal of Organic Chemistry, vol. 1, pp. 71-77, 2011.

[96] C. Mallikarjunaswamy, D. G. Bhadregowda, and L. Mallesha, "Synthesis and antimicrobial activity of pyrimidine salts with chloranilic and picric acids," Journal of Chemistry, vol. 2013, Article ID 727182, 5 pages, 2013.

[97] N. Zanatta, S. S. Amaral, J. M. dos Santos et al., "Convergent synthesis and cruzain inhibitory activity of novel $2-\left(\mathrm{N}^{\prime}\right.$ benzylidenehydrazino)-4-trifluoromethyl-pyrimidines," Bioorganic and Medicinal Chemistry, vol. 16, no. 24, pp. 10236-10243, 2008.

[98] A. M. Balan, O. Florea, C. Moldoveanu, G. Zbancioc, D. Iurea, and I. I. Mangalagiu, "Diazinium salts with dihydroxyacetophenone skeleton: syntheses and antimicrobial activity," European Journal of Medicinal Chemistry, vol. 44, no. 5, pp. 2275-2279, 2009.

[99] P. Mondal, S. Jana, and L. K. Kanthal, "Synthesis of novel mercapto-pyrimidine and amino-pyrimidine derivatives of indoline-2-one as potential antioxidant \& antibacterial agents," The Pharma Research, vol. 3, pp. 17-26, 2010.

[100] A. Solankee, S. Lad, S. Solankee, and G. Patel, "Chalcones, pyrazolines and aminopyrimidines as antibacterial agents," Indian Journal of Chemistry B, vol. 48, no. 10, pp. 1442-1446, 2009.

[101] S. Sukhwal and B. L. Verma, "A new route to 2-piperidino-4,6diarylpyrimidines," Indian Journal of Heterocyclic Chemistry, vol. 4, no. 1, pp. 67-68, 1994. 
[102] V. Desai, C. M. Desai, and D. Patel, "2-Amino-4-(4'chlorophenyl)-6-substituted)-pyrimidines," Journal of the Institution of Chemists, vol. 11, pp. 104-105, 2005.

[103] A. A. F. Wasfy and A. A. Aly, "Simple synthesis of some diphenylsulfapyrimidine acetates from chalcones and their antimicrobial activity," Chemical Papers, vol. 57, no. 5, pp. 364368, 2003.

[104] E. S. Devi, E. O. Prakash, and J. T. Rao, "Pyrimidine derivatives part-1," Journal of the Institution of Chemists, vol. 74, no. 5, pp. 167-168, 2002.

[105] D. B. Yadav, K. B. Venkatesh, and S. S. Sangapure, "Synthesis and biological evaluation of 3-aryl-1-(2-benzofuryl)-2-propen1-one analogues," Indian Journal of Heterocyclic Chemistry, vol. 19, no. 2, pp. 117-120, 2009.

[106] S. Kothari, R. Vyas, and B. L. Verma, "A facile one pot conversion of $3^{\prime}, 5^{\prime}$-dibromo- $4^{\prime}$-hydroxy substituted chalcones to pyrimidine derivatives and their antibacterial and herbicidal activity," Indian Journal of Heterocyclic Chemistry, vol. 8, no. 4, pp. 285-288, 1999.

[107] V. H. Babu, P. S. Kumar, K. K. Srinivasan, and G. V. Bhat, "Synthesis, antitumor and antibacterial activities of certain substituted pyrimidines bearing benzofuran," Indian Journal of Pharmaceutical Sciences, vol. 66, no. 5, pp. 647-652, 2004.

[108] T. Y. Pasha, R. H. Udupi, and A. R. Bhat, "Synthesis and antimicrobial screening of some pyrimidine derivatives," Indian Journal of Heterocyclic Chemistry, vol. 15, no. 2, pp. 149-152, 2005.

[109] S. Chandrasekaran and S. Nagarajan, "Microwave-assisted synthesis and anti-bacterial activity of some 2-amino-6-aryl-4-(2thienyl)pyrimidines," Il Farmaco, vol. 60, no. 4, pp. 279-282, 2005.

[110] A. A. Patel and A. G. Mehta, "Synthesis and characterization of some pyrimidine-quinoline clubbed molecules and their microbicidal efficacy," Journal of Saudi Chemical Society, vol. 14, no. 2, pp. 203-208, 2010.

[111] D. B. A. Kumar, G. K. Prakash, M. N. Kumaraswamy, B. P. Nandeshwarappa, B. S. Sherigara, and K. M. Mahadevan, "Microwave assisted facile synthesis of amino pyrimidines bearing benzofuran and investigation of their antimicrobial activity," Indian Journal of Chemistry B, vol. 45, no. 7, pp. 16991703, 2006.

[112] V. Kanagarajan, J. Thanusu, and M. Gopalakrishnan, "A green chemical approach towards the "one-pot" synthesis, spectral characterization and in vitro antibacterial and antifungal activities of morpholino pyrimidines," Journal of the Korean Chemical Society, vol. 53, no. 6, pp. 731-741, 2009.

[113] T. A. Naik and K. H. Chikhalia, "Studies on synthesis of pyrimidine derivatives and their pharmacological evaluation," E-Journal of Chemistry, vol. 4, no. 1, pp. 60-66, 2007.

[114] V. K. Tirlapur, N. Gandhi, R. Basawaraj, and P. Y. Rajendra, "Synthesis, characterization and biological activities of some new pyrimidines and isoxazoles bearing benzofuran moiety," International Journal of ChemTech Research, vol. 2, no. 3, pp. 1434-1440, 2010.

[115] N. Ingarsal, G. Saravanan, P. Amutha, and S. Nagarajan, "Synthesis, in vitro antibacterial and antifungal evaluations of 2amino-4-(1-naphthyl)-6-arylpyrimidines," European Journal of Medicinal Chemistry, vol. 42, no. 4, pp. 517-520, 2007.

[116] B. Ramesh and T. Sumana, "Synthesis and anti-microbial screening of some new pyrimidine derivatives," International Journal of Pharmaceutical Sciences, vol. 1, no. 2, pp. 320-322, 2009.
[117] L. R. Patil, V. S. Ingle, S. P. Bondge, V. E. Bhingolikar, and R. A. Mane, "Synthesis of new pyrimidines bearing paracetamol and imidazolyl moieties," Indian Journal of Heterocyclic Chemistry, vol. 11, no. 2, pp. 131-134, 2001.

[118] D. H. Patel, K. H. Chikhalia, N. K. Shah, D. P. Patel, P. B. Kaswala, and V. M. Buha, "Design, synthesis and antimicrobial study of some pyrimidine derivatives," Pharmaceutical Chemistry Journal, vol. 44, no. 2, pp. 94-98, 2010.

[119] R. A. Forsch, S. F. Queener, and A. Rosowsky, "Preliminary in vitro studies on two potent, water-soluble trimethoprim analogues with exceptional species selectivity against dihydrofolate reductase from Pneumocystis carinii and Mycobacterium avium," Bioorganic and Medicinal Chemistry Letters, vol. 14, no. 7, pp. 1811-1815, 2004.

[120] A. Ali, S. D. Aster, D. W. Graham et al., "Design and synthesis of novel antibacterial agents with inhibitory activity against DNA polymerase III," Bioorganic and Medicinal Chemistry Letters, vol. 11, no. 16, pp. 2185-2188, 2001.

[121] G. Menozzi, L. Mosti, P. Fossa, C. Musiu, C. Murgioni, and P. La Colla, "Synthesis and biological evaluation of azole derivatives, analogues of bifonazole, with a phenylisoxazolyl or phenylpyrimidinyl moiety," Il Farmaco, vol. 56, no. 9, pp. 633640, 2001.

[122] E. Nassar, "Synthesis, (in vitro) antitumour and antimicrobial activity of some pyrazoline, pyridine and pyrimidine derivatives linked to indole moiety," Journal of American Science, vol. 6, no. 8, pp. 338-347, 2010.

[123] A. Nagaraj and C. S. Reddy, "Synthesis and biological study of novel bis-chalcones, bis-thiazines and bis-pyrimidines," Journal of the Iranian Chemical Society, vol. 5, no. 2, pp. 262-267, 2008.

[124] O. A. Fathalla, W. A. Zaghary, H. H. Radwan, S. M. Awad, and M. S. Mohamed, "Synthesis of new 2-thiouracil-5-sulfonamide derivatives with biological activity," Archives of Pharmacal Research, vol. 25, no. 3, pp. 258-269, 2002.

[125] K. H. Chikhalia, M. J. Patel, and D. B. Vashi, "Design, synthesis and evaluation of novel quinolyl chalcones as antibacterial agents," Arkivoc, vol. 2008, no. 13, pp. 189-197, 2008.

[126] P. C. Wyss, P. Gerber, P. G. Hartman et al., "Novel dihydrofolate reductase inhibitors. Structure-based versus diversity-based library design and high-throughput synthesis and screening," Journal of Medicinal Chemistry, vol. 46, no. 12, pp. 2304-2312, 2003.

[127] M. Brands, Y. C. Grande, R. Endermann, R. Gahlmann, J. Krüger, and S. Raddatz, "Pyrimidinone antibioticsheterocyclic analogues with improved antibacterial spectrum," Bioorganic and Medicinal Chemistry Letters, vol. 13, no. 16, pp. 2641-2645, 2003.

[128] K. Vijayaramalingam, S. Chandrasekaran, and S. Nagarajan, "Synthesis and antibacterial activity of 4-(1-naphthyl)-6arylpyrimidin-2-(1H)-ones," Pharmaceutical Chemistry Journal, vol. 41, no. 5, pp. 253-255, 2007.

[129] B. Orzeszko, Z. Kazimierczuk, J. K. Maurin et al., "Novel adamantylated pyrimidines and their preliminary biological evaluations," Il Farmaco, vol. 59, no. 12, pp. 929-937, 2004.

[130] A. H. Moustafa, H. A. Saad, W. S. Shehab, and M. M. ElMobayed, "Synthesis of some new pyrimidine derivatives of expected antimicrobial activity," Phosphorus, Sulfur and Silicon and the Related Elements, vol. 183, no. 1, pp. 115-135, 2008.

[131] M. M. M. Ramiz, W. A. El-Sayed, A. I. El-Tantawy, and A. A. H. Abdel-Rahman, "Antimicrobial activity of new 4,6disubstituted pyrimidine, pyrazoline, and pyran derivatives," Archives of Pharmacal Research, vol. 33, no. 5, pp. 647-654, 2010. 
[132] P. Černuchová, G. Vo-Thanh, V. Milata, A. Loupy, S. Jantová, and M. Theiszová, "Utilization of 2-ethoxymethylene-3oxobutanenitrile in the synthesis of heterocycles possessing biological activity," Tetrahedron, vol. 61, no. 22, pp. 5379-5387, 2005.

[133] S. L. Mosley, B. A. Bakke, J. M. Sadler et al., "Carbocyclic pyrimidine nucleosides as inhibitors of $S$-adenosylhomocysteine hydrolase," Bioorganic and Medicinal Chemistry, vol. 14, no. 23, pp. 7967-7971, 2006.

[134] J. A. A. Micky, N. M. Saleh, S. M. Mohamed, S. A. Mohamed, and M. M. Salem, "Reaction and antimicrobial activity of 1arylethylene benzofuranyl ketone derivatives," Indian Journal of Chemistry B, vol. 45, no. 6, pp. 1579-1583, 2006.

[135] N. B. Patel and Y. S. Gorgamwala, "Antibacterial study of 2-(Pyrazine- $2^{\prime}$-carboxamido)-4-(2'-p-aminobenzene-sulfonamido- $4^{\prime}, 6^{\prime}$-dimethyl pyrimidine)-6-(arylthiouriedo)-striazine derivatives," Journal of Indian Council of Chemists, vol. 19, no. 2, pp. 17-20, 2002.

[136] S. A. Rahaman, Y. R. Prasad, K. P. Kumar, D. Hareesh, and A. P. Rani, "Synthesis and in vitro antibacterial activity of some novel 2-amino-4,6-D derivatives," Journal of Sciences, Islamic Republic of Iran, vol. 22, no. 1, pp. 27-31, 2011.

[137] S. G. Khanage, S. A. Raju, P. B. Mohite, and R. B. Pandhare, "Synthesis and pharmacological evaluation of some new pyrimidine derivatives containing 1,2,4-triazole," Advanced Pharmaceutical Bulletin, vol. 2, no. 2, pp. 213-222, 2012.

[138] N. Kaur, A. K. Aggarwal, N. Sharma, and B. Choudhary, "Synthesis and in-vitro antimicrobial activity of pyrimidine derivatives," International Journal of Pharmaceutical Sciences and Drug Research, vol. 4, no. 3, pp. 199-204, 2012.

[139] M. M. M. Hussain, K. I. Bhat, B. C. Revanasiddappa, and D. R. Bharthi, "Synthesis and biological evaluation of some novel 2mercapto pyrimidines," International Journal of Pharmacy and Pharmaceutical Sciences, vol. 5, no. 2, pp. 471-473, 2013.

[140] A. A. Aly and S. A. Nassar, "N-[4-(dicyanomethylazo)phenyl]2-saccharin-2-ylacetamide in the synthesis of pyridazine and pyrimidine derivatives," Heteroatom Chemistry, vol. 15, no. 1, pp. 2-8, 2004.

[141] A. Waheed, M. S. Alorainy, A. A. Alghasham, S. A. Khan, and M. Raza, "Synthesis of a new series of substituted pyrimidines and its evaluation for antibacterial and antinociceptive effects," International Journal of Health Sciences, vol. 2, no. 1, pp. 39-48, 2008.

[142] J. M. Parmar and A. R. Parikh, "Synthesis and biological evaluation of some pyrimidinethiones and related heterocycles," Indian Journal of Heterocyclic Chemistry, vol. 10, no. 3, pp. 205208, 2001.

[143] N. Y. Khir Eldin, W. A. Gad, Y. M. Ali, and N. R. Mohamed, “The utility of 6-amino-2-thiouracil for synthesis of bioactive sulfur and phosphorus heterocyclic derivatives," Egyptian Journal of Chemistry, vol. 50, no. 4, pp. 531-540, 2007.

[144] M. N. Purohi, C. Kunal, G. V. Pujar, Y. C. Mayur, and S. M. Shantakumar, "Synthesis and antibacterial activity of 5-(5' -substituted 1,3,4-oxadiazol-2' -YL) dihydropyrimidinone derivatives," Indian Journal of Heterocyclic Chemistry, vol. 16, no. 4, pp. 349-352, 2007.

[145] A. H. Moustafa, H. A. Morsy, M. G. Assy, and A. Z. Haikal, "Synthesis and antimicrobial activity of some S- $\beta$-D-glucosides of 4-mercaptopyrimidine," Nucleosides, Nucleotides and Nucleic Acids, vol. 28, no. 9, pp. 835-845, 2009.
[146] D. N. Upadhyay and V. J. Ram, "Synthesis of pyrimidine and azolopyrimidines as biodynamic agents," Indian Journal of Chemistry B, vol. 38, no. 2, pp. 173-177, 1999.

[147] O. A. El-Fattah, E. M. H. Abbas, N. A. Mohamed, and S. I. AbdElmoez, "Synthesis and evaluation of some tetrahydropyrimidine derivatives as antimicrobial," Australian Journal of Basic and Applied Sciences, vol. 4, no. 1, pp. 27-36, 2010.

[148] A. H. Moustafa, H. A. Morsy, and A. Z. Haikal, "Synthesis and antimicrobial activity of some S-and-N- $\beta$-D-glucosides of pyrimidin-4-thiol," in Proceedings of the 4th Environmental Conference, pp. 47-63, Faculty of Science, Zigzag University, 2009.

[149] T. Tomašić, N. Zidar, M. Mueller-Premru, D. Kikelj, and L. P. Mašič, "Synthesis and antibacterial activity of 5-ylidenethiazolidin-4-ones and 5-benzylidene-4,6pyrimidinediones," European Journal of Medicinal Chemistry, vol. 45, no. 4, pp. 1667-1672, 2010.

[150] O. A. Fathalla, I. F. Zied, M. E. Haiba et al., "Synthesis, antibacterial and anticancer evaluation of some pyrimidine derivatives," World Journal of Chemistry, vol. 4, pp. 127-132, 2009.

[151] L. C. Heda, R. Sharma, C. Pareek, and P. B. Chaudhari, "Synthesis and antimicrobial activity of some derivatives of 5substituted indole dihydropyrimidines," E-Journal of Chemistry, vol. 6, no. 3, pp. 770-774, 2009.

[152] S. Prachayasittikul, N. Sornsongkhram, R. Pingaew, S. Techatanachai, S. Ruchirawat, and V. Prachayasittikul, "Synthesis and novel bioactivities of substituted 6propylthiouracils," European Journal of Scientific Research, vol. 36, no. 2, pp. 236-245, 2009.

[153] H. S. Basavaraja, K. V. Jayadevaiah, M. M. Hussain, V. Kumar, and B. Padmashali, "Synthesis of novel piperazine and morpholine linked substituted pyrimidine derivatives as antimicrobial agents," Journal of Pharmaceutical Sciences and Research, vol. 2, no. 1, pp. 5-12, 2010

[154] J. D. Akbari, P. K. Kachhadia, S. D. Tala et al., "Synthesis of some new 1,2,3,4-tetrahydropyrimidine-2-thiones and their thiazolo[3,2- $\alpha]$ pyrimidine derivatives as potential biological agents," Phosphorus, Sulfur and Silicon and the Related Elements, vol. 183, no. 8, pp. 1911-1922, 2008.

[155] A. A. Bekhit, O. A. El-Sayed, E. Aboulmagd, and J. Y. Park, "Tetrazolo[1,5-a]quinoline as a potential promising new scaffold for the synthesis of novel anti-inflammatory and antibacterial agents," European Journal of Medicinal Chemistry, vol. 39, no. 3, pp. 249-255, 2004.

[156] Q. Yan, R. Cao, W. Yi et al., "Inhibitory effects of 5-benzylidene barbiturate derivatives on mushroom tyrosinase and their antibacterial activities," European Journal of Medicinal Chemistry, vol. 44, no. 10, pp. 4235-4243, 2009.

[157] S. N. Sriharsha, S. Satish, S. Shashikanth, and K. A. Raveesha, "Design, synthesis and antibacterial activity of novel 1,3thiazolidine pyrimidine nucleoside analogues," Bioorganic and Medicinal Chemistry, vol. 14, no. 22, pp. 7476-7481, 2006.

[158] A. Padmaja, T. Payani, G. D. Reddy, and V. Padmavathi, "Synthesis, antimicrobial and antioxidant activities of substituted pyrazoles, isoxazoles, pyrimidine and thioxopyrimidine derivatives," European Journal of Medicinal Chemistry, vol. 44, no. 11, pp. 4557-4566, 2009.

[159] A. R. Gholap, K. S. Toti, F. Shirazi, M. V. Deshpande, and K. V. Srinivasan, "Efficient synthesis of antifungal pyrimidines via 
palladium catalyzed Suzuki/Sonogashira cross-coupling reaction from Biginelli 3,4-dihydropyrimidin-2(1H)-ones," Tetrahedron, vol. 64, no. 44, pp. 10214-10223, 2008.

[160] K. K. Joshi, J. Akbari, and H. S. Joshi, "Evaluations of antimicrobial activity of some pharmacological important dihydropyrimidines compounds," Journal of Cell and Tissue Research, vol. 10, no. 2, pp. 2243-2250, 2010.

[161] P. Sharma, A. Kumar, and M. Sharma, "Synthesis and QSAR studies on 5-[2-(2-methylpropl-enyl)-1H benzimidazol-1yl]4,6-diphenyl-pyrimidin-2-(5H)-thione derivatives as antibacterial agents," European Journal of Medicinal Chemistry, vol. 41, no. 7, pp. 833-840, 2006.

[162] E. Septioğlu, M. D. Aytemir, E. Kiliç, M. Özalp, and U. Çaliş, "Synthesis of some new N,N-disubstituted dithiocarbamic acid 2-(6-arylhexahydropyrimidine-2,4-dion-3-yl)ethyl esters and in vitro evaluation of antimicrobial activities," FABAD Journal of Pharmaceutical Sciences, vol. 29, no. 1, pp. 1-6, 2004.

[163] C. Robson, M. A. Meek, J.-D. Grunwaldt et al., "Nonclassical 2,4-diamino-5-aryl-6-ethylpyrimidine antifolates: activity as inhibitors of dihydrofolate reductase from Pneumocystis carinii and Toxoplasma gondii and as antitumor agents," Journal of Medicinal Chemistry, vol. 40, no. 19, pp. 3040-3048, 1997.

[164] D. V. Singh, A. R. Mishra, and R. M. Mishra, "Synthesis and characterization of some antifungal pyrimidinone derivatives," Indian Journal of Heterocyclic Chemistry, vol. 14, no. 1, pp. 4346, 2004.

[165] R. Bamnela and S. P. Shrivastava, "Synthesis and in vitro antimicrobial, anthelmintic and insecticidal activities study of 4(4'-bromophenyl)-6-substituted-aryl-1-acetyl pyrimidine2-thiols," E-Journal of Chemistry, vol. 7, no. 3, pp. 935-941, 2010.

[166] D. J. Trantolo, G. E. Wright, and N. C. Brown, "Inhibitors of Bacillus subtilis DNA polymerase III. Influence of modifications in the pyrimidine ring of anilino- and (benzylamino)pyrimidines," Journal of Medicinal Chemistry, vol. 29, no. 5, pp. 676-681, 1986.

[167] B. Shivkumar, S. Singh, T. Y. Pasha et al., "Synthesis of certain pyrimidines as antimicrobial agents," Indian Journal of Heterocyclic Chemistry, vol. 17, no. 2, pp. 197-198, 2007.

[168] B. D. Dhorajiya, M. H. Malani, J. R. Patel, and B. Z. Dholakiya, "Antimicrobial activities of synthesized and characterized 5acetyl pyrimidine-2,4,6-(1H,3H,5H)-trione based chalcones," Der Pharma Chemica, vol. 4, no. 1, pp. 141-146, 2012.

[169] K. Elumalai, M. A. Ali, M. Elumalai, K. Eluri, and S. Srinivasan, "Novel isoniazid cyclocondensed 1,2,3,4-tetrahydropyrimidine derivatives for treating infectious disease: a synthesis and in vitro biological evaluation," Journal of Acute Disease, vol. 2, no. 4, pp. 316-321, 2013.

[170] B. Andrews and M. Ahmed, "Synthesis and characterization of pyrimidine bearing 1,3,4-oxadiazole derivatives and their potential antifungal action," International Journal of Chemical Studies, vol. 1, no. 4, pp. 32-39, 2013.

[171] H. Sohn, K.-S. Lee, Y.-K. Ko et al., "In vitro and ex vivo activity of new derivatives of acetohydroxyacid synthase inhibitors against Mycobacterium tuberculosis and non-tuberculous mycobacteria," International Journal of Antimicrobial Agents, vol. 31, no. 6, pp. 567-571, 2008.

[172] A. Rosowsky, R. A. Forsch, and S. F. Queener, "Inhibition of Pneumocystis carinii, Toxoplasma gondii, and Mycobacterium avium dihydrofolate reductases by 2,4-diamino-5-[2-methoxy5-( $\omega$-carboxyalkyloxy)benzyl]pyrimidines: marked improvement in potency relative to trimethoprim and species selectivity relative to piritrexim," Journal of Medicinal Chemistry, vol. 45, no. 1, pp. 233-241, 2002.

[173] R. C. Reynolds, S. R. Campbell, R. G. Fairchild et al., "Novel boron-containing, nonclassical antifolates: synthesis and preliminary biological and structural evaluation," Journal of Medicinal Chemistry, vol. 50, no. 14, pp. 3283-3289, 2007.

[174] A. R. Trivedi, D. K. Dodiya, N. R. Ravat, and V. H. Shah, "Synthesis and biological evaluation of some new pyrimidines via a novel chalcone series," Arkivoc, vol. 2008, no. 11, pp. 131-141, 2008.

[175] M. L. Read, M. Brændvang, P. O. Miranda, and L. Gundersen, "Synthesis and biological evaluation of pyrimidine analogs of antimycobacterial purines," Bioorganic and Medicinal Chemistry, vol. 18, no. 11, pp. 3885-3897, 2010.

[176] K. Umaa, M. Ramanathan, K. Krishnakumar, and K. Kannan, "Elucidation and evaluation of substituted pyrimidines," Asian Journal of Chemistry, vol. 21, no. 9, pp. 6674-6678, 2009.

[177] A. A. Siddiqui, R. Rajesh, M. Islam, V. Alagarsamy, and E. de Clercq, "Synthesis, antiviral, antituberculostic, and antibacterial activities of some novel, 4-(4-substituted phenyl)-6(4-nitrophenyl)-2-(substituted imino)pyrimidines," Archiv der Pharmazie, vol. 340, no. 2, pp. 95-102, 2007.

[178] V. Virsodia, R. R. S. Pissurlenkar, D. Manvar et al., "Synthesis, screening for antitubercular activity and 3D-QSAR studies of substituted N-phenyl-6-methyl-2-oxo-4-phenyl-1,2,3,4tetrahydro-pyrimidine-5-carboxamides," European Journal of Medicinal Chemistry, vol. 43, no. 10, pp. 2103-2115, 2008.

[179] N. C. Srivastav, T. Manning, D. Y. Kunimoto, and R. Kumar, "Studies on acyclic pyrimidines as inhibitors of mycobacteria," Bioorganic and Medicinal Chemistry, vol. 15, no. 5, pp. 20452053, 2007.

[180] N. C. Srivastav, D. Rai, C. Tse, B. Agrawal, D. Y. Kunimoto, and R. Kumar, "Inhibition of mycobacterial replication by pyrimidines possessing various C-5 functionalities and related $2^{\prime}$ deoxynucleoside analogues using in vitro and in vivo models," Journal of Medicinal Chemistry, vol. 53, no. 16, pp. 6180-6187, 2010.

[181] M. Johar, T. Manning, C. Tse et al., "Growth inhibition of Mycobacterium bovis, Mycobacterium tuberculosis and Mycobacterium avium in vitro: effect of $1-\beta-\mathrm{D}-2^{\prime}$ arabinofuranosyl and $1-\left(2^{\prime}\right.$-deoxy- $2^{\prime}$-fluoro- $\beta$-D- $2^{\prime}$-ribofuranosyl) pyrimidine nucleoside analogs," Journal of Medicinal Chemistry, vol. 50, no. 15, pp. 3696-3705, 2007.

[182] A. Agarwal, K. Srivastava, S. K. Puri, and P. M. S. Chauhan, "Synthesis of 2,4,6-trisubstituted pyrimidines as antimalarial agents," Bioorganic and Medicinal Chemistry, vol. 13, no. 15, pp. 4645-4650, 2005.

[183] B. Tarnchompoo, C. Sirichaiwat, W. Phupong et al., "Development of 2,4-diaminopyrimidines as antimalarials based on inhibition of the S108N and C59R+S108N mutants of dihydrofolate reductase from pyrimethamine resistant Plasmodium falciparum," Journal of Medicinal Chemistry, vol. 45, no. 6, pp. 1244-1252, 2002.

[184] J. M. Coterón, D. Catterick, J. Castro et al., "Falcipain inhibitors: optimization studies of the 2-pyrimidinecarbonitrile lead series," Journal of Medicinal Chemistry, vol. 53, no. 16, pp. 6129-6152, 2010

[185] M. A. Dea-Ayuela, E. Castillo, M. Gonzalez-Alvarez et al., "In vivo and in vitro anti-leishmanial activities of 4-nitro$\mathrm{N}$-pyrimidinand N-pyrazin-2-ylbenzenesulfonamides, and $\mathrm{N}^{2}$ (4-nitrophenyl)- $\mathrm{N}^{1}$ propylglycinamide," Bioorganic and Medicinal Chemistry, vol. 17, no. 21, pp. 7449-7456, 2009. 
[186] L. Gupta, N. Sunduru, A. Verma et al., "Synthesis and biological evaluation of new $[1,2,4]$ triazino[5,6-b]indol-3-ylthio-1,3,5triazines and $[1,2,4]$ triazino[5,6-b]indol-3-ylthio-pyrimidines against Leishmania donovani," European Journal of Medicinal Chemistry, vol. 45, no. 6, pp. 2359-2365, 2010.

[187] S. F. Chowdhury, V. B. Villamor, R. H. Guerrero et al., "Design, synthesis, and evaluation of inhibitors of trypanosomal and leishmanial dihydrofolate reductase," Journal of Medicinal Chemistry, vol. 42, no. 21, pp. 4300-4312, 1999.

[188] N. Chandra, R. Ramesh, A. Ashutosh, N. Goyal, S. N. Suryawanshi, and S. Gupta, "Antileishmanial agents part-IV: synthesis and antileishmanial activity of novel terpenyl pyrimidines," European Journal of Medicinal Chemistry, vol. 40, no. 6, pp. 552556, 2005.

[189] H. Parveen, F. Hayat, A. Salahuddin, and A. Azam, "Synthesis, characterization and biological evaluation of novel 6ferrocenyl-4-aryl-2-substituted pyrimidine derivatives," European Journal of Medicinal Chemistry, vol. 45, no. 8, pp. 34973503, 2010.

[190] B. K. Singh, M. Mishra, N. Saxena et al., "Synthesis of 2-sulfanyl6-methyl-1,4-dihydropyrimidines as a new class of antifilarial agents," European Journal of Medicinal Chemistry, vol. 43, no. 12, pp. 2717-2723, 2008.

[191] P. Selvam, M. Chandramohan, E. de Clercq, M. Witvrouw, and C. Pannecouque, "Synthesis and anti-HIV activity of 4-[(1,2dihydro-2-oxo-3H-indol-3-ylidene) amino]-N(4,6-dimethyl2-pyrimidinyl)-benzene sulfonamide and its derivatives," European Journal of Pharmaceutical Sciences, vol. 14, no. 4, pp. 313-316, 2001.

[192] A. Holý, I. Votruba, M. Masojídková et al., “6-[2(Phosphonomethoxy)alkoxy]pyrimidines with antiviral activity," Journal of Medicinal Chemistry, vol. 45, no. 9, pp. 1918-1929, 2002.

[193] D. Sriram, T. R. Bal, and P. Yogeeswari, "Aminopyimidinimo isatin analogues: design of novel non-nucleoside HIV-1 reverse transcriptase inhibitors with broadspectrum chemotherapeutic properties," Journal of Pharmacy and Pharmaceutical Sciences, vol. 8, no. 3, pp. 565-577, 2005.

[194] A. Mai, M. Artico, G. Sbardella et al., "5-alkyl-2-(alkylthio)6-(2,6-dihalophenylmethyl)-3,4-dihydropyrimidin-4(3H)ones: novel potent and selective dihydro-alkoxy-benzyloxopyrimidine derivatives," Journal of Medicinal Chemistry, vol. 42, no. 4, pp. 619-627, 1999.

[195] D. Hocková, A. Holý, M. Masojídková et al., "Synthesis and antiviral activity of 2,4-diamino-5-cyano-6-[2-(phosphonomethoxy)ethoxy]pyrimidine and related compounds," Bioorganic and Medicinal Chemistry, vol. 12, no. 12, pp. 31973202, 2004.

[196] S. F. Mohamed, E. M. Flefel, A. E. E. Amr, and D. N. Abd ElShafy, "Anti-HSV-1 activity and mechanism of action of some new synthesized substituted pyrimidine, thiopyrimidine and thiazolopyrimidine derivatives," European Journal of Medicinal Chemistry, vol. 45, no. 4, pp. 1494-1501, 2010.

[197] M. B. Nawrozkij, D. Rotili, D. Tarantino et al., "5-alkyl-6benzyl-2-(2-oxo-2-phenylethylsulfanyl)pyrimidin-4 $(3 \mathrm{H})$ ones, a series of anti-HIV-1 agents of the dihydro-alkoxybenzyl-oxopyrimidine family with peculiar structure-activity relationship profile," Journal of Medicinal Chemistry, vol. 51, no. 15, pp. 4641-4652, 2008.
[198] V. Summa, A. Petrocchi, V. G. Matassa et al., "HCV NS5b RNA-dependent RNA polymerase inhibitors: from $\alpha, \gamma$ diketoacids to 4,5-dihydroxypyrimidine- or 3-methyl-5hydroxypyrimidinonecarboxylic acids. Design and synthesis," Journal of Medicinal Chemistry, vol. 47, no. 22, pp. 5336-5339, 2004.

[199] U. Koch, B. Attenni, S. Malancona et al., "2-(2-Thienyl)-5,6dihydroxy-4-carboxypyrimidines as inhibitors of the hepatitis $C$ virus NS5B polymerase: discovery, SAR, modeling, and mutagenesis," Journal of Medicinal Chemistry, vol. 49, no. 5, pp. 1693-1705, 2006.

[200] F. Manetti, J. A. Esté, I. Clotet-Codina et al., "Parallel solutionphase and microwave-assisted synthesis of new S-DABO derivatives endowed with subnanomolar anti-HIV-1 activity," Journal of Medicinal Chemistry, vol. 48, no. 25, pp. 8000-8008, 2005.

[201] S. Prekupec, D. Makuc, J. Plavec et al., "Novel C-6 fluorinated acyclic side chain pyrimidine derivatives: synthesis, ${ }^{1} \mathrm{H}$ and ${ }^{13} \mathrm{C}$ NMR conformational studies, and antiviral and cytostatic evaluations," Journal of Medicinal Chemistry, vol. 50, no. 13, pp. 3037-3045, 2007. 

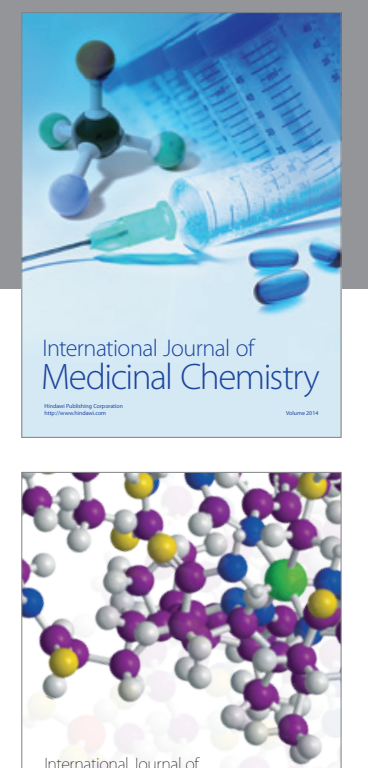

\section{Carbohydrate} Chemistry

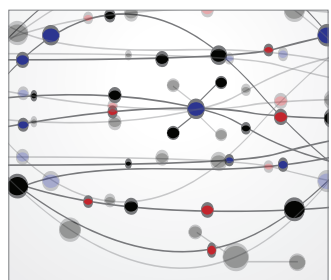

The Scientific World Journal
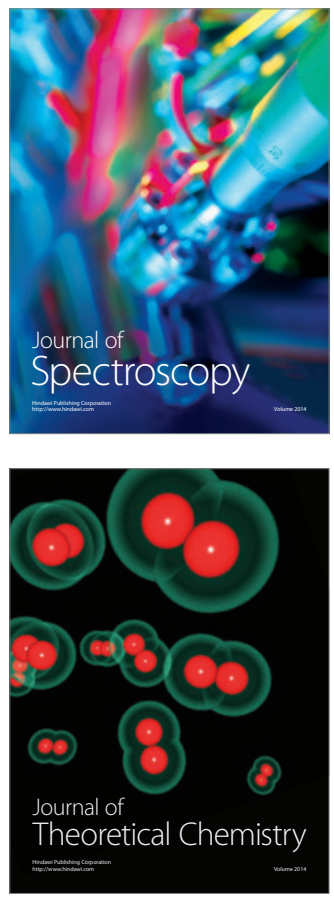
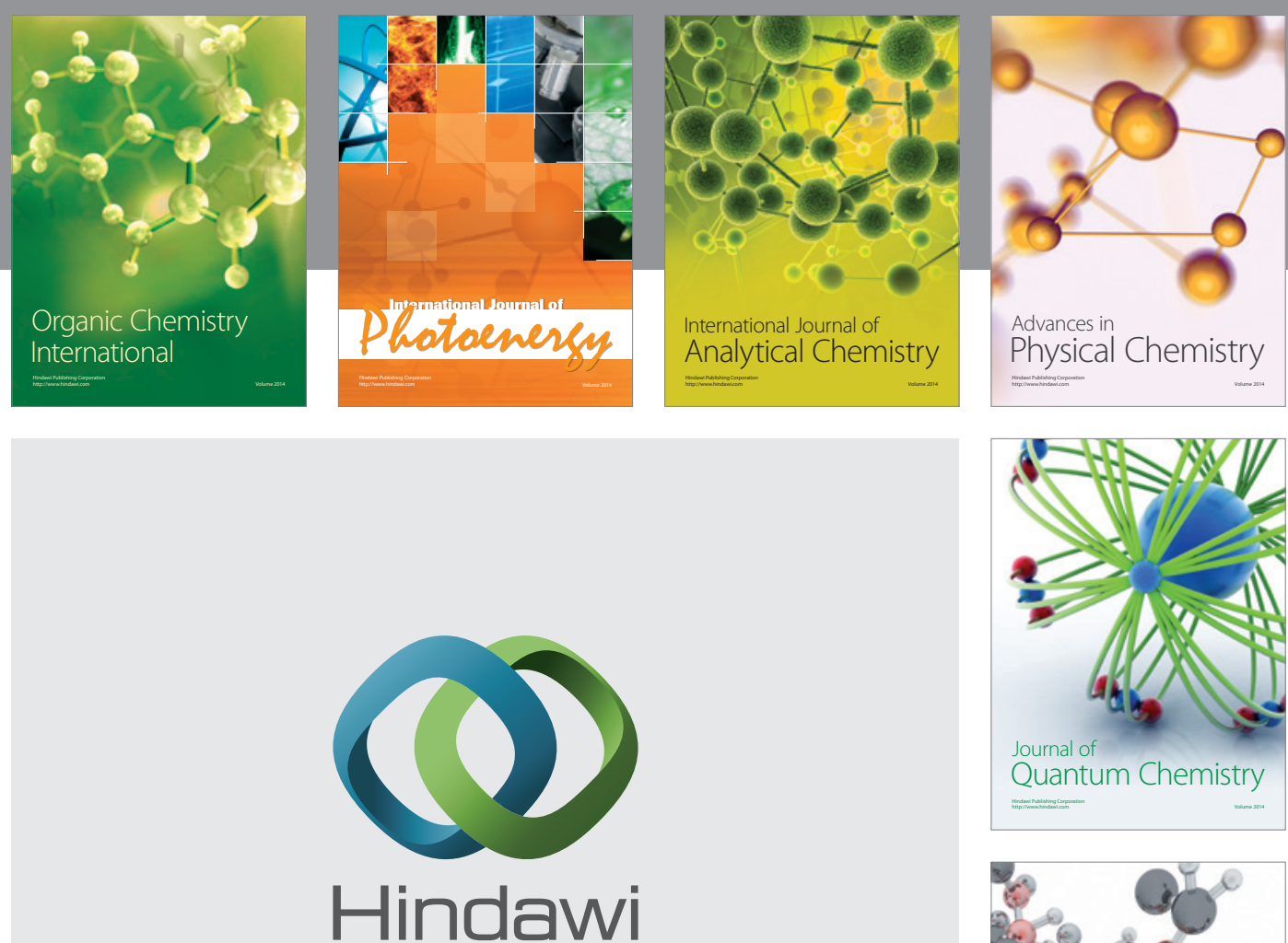

Submit your manuscripts at

http://www.hindawi.com

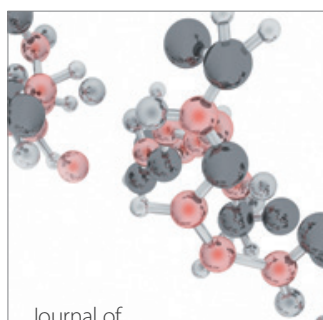

Analytical Methods

in Chemistry

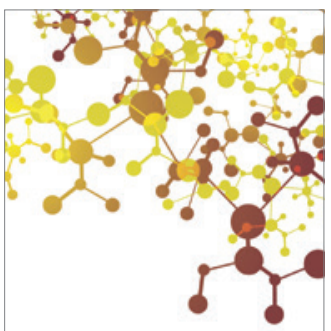

Journal of

Applied Chemistry

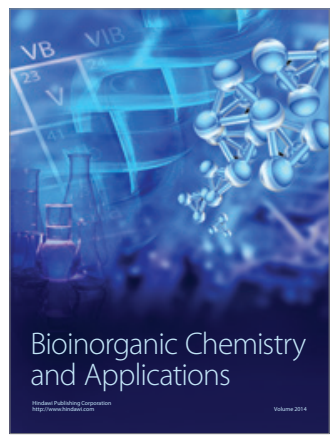

Inorganic Chemistry
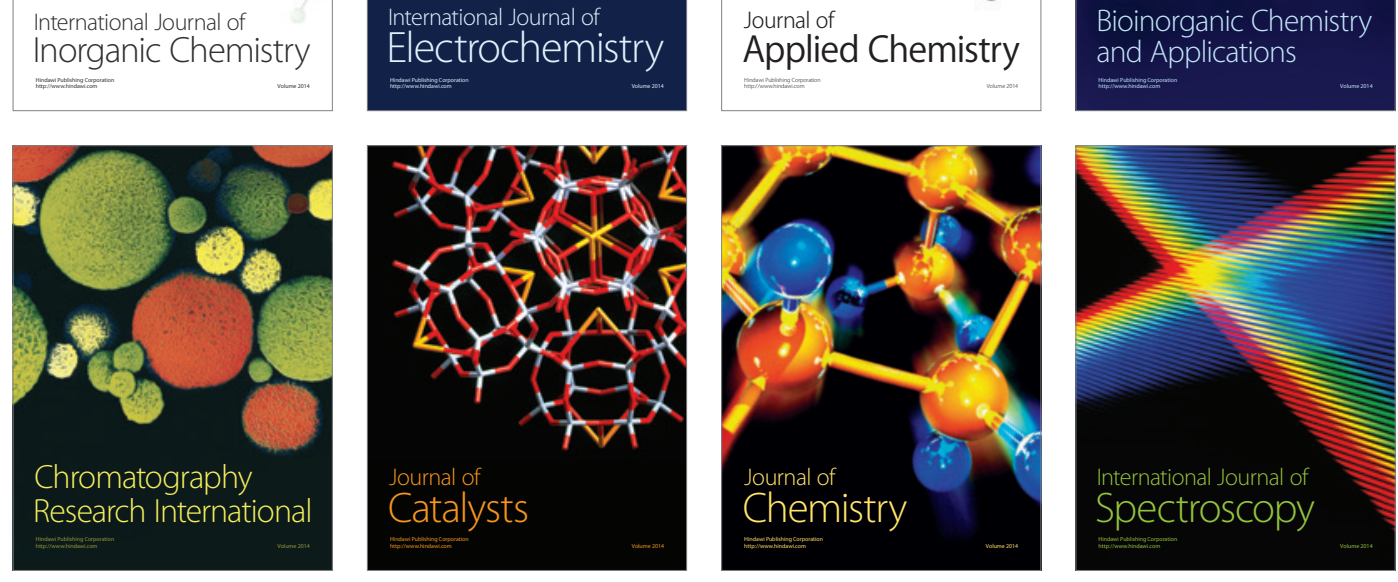